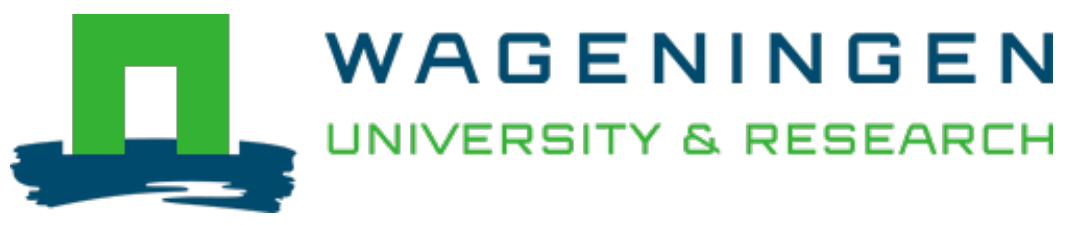

\title{
Pectobacterium and Dickeya: Environment to Disease Development
}

Plant Diseases Caused by Dickeya and Pectobacterium Species

Toth, I.K.; Barny, Marie-Anne; Brurberg, M.B.; Condemine, G.; Czajkowski, R.L. et al https://doi.org/10.1007/978-3-030-61459-1_3

This article is made publicly available in the institutional repository of Wageningen University and Research, under the terms of article $25 \mathrm{fa}$ of the Dutch Copyright Act, also known as the Amendment Taverne. This has been done with explicit consent by the author.

Article $25 \mathrm{fa}$ states that the author of a short scientific work funded either wholly or partially by Dutch public funds is entitled to make that work publicly available for no consideration following a reasonable period of time after the work was first published, provided that clear reference is made to the source of the first publication of the work.

This publication is distributed under The Association of Universities in the Netherlands (VSNU) 'Article $25 \mathrm{fa}$ implementation' project. In this project research outputs of researchers employed by Dutch Universities that comply with the legal requirements of Article $25 \mathrm{fa}$ of the Dutch Copyright Act are distributed online and free of cost or other barriers in institutional repositories. Research outputs are distributed six months after their first online publication in the original published version and with proper attribution to the source of the original publication.

You are permitted to download and use the publication for personal purposes. All rights remain with the author(s) and / or copyright owner(s) of this work. Any use of the publication or parts of it other than authorised under article $25 \mathrm{fa}$ of the Dutch Copyright act is prohibited. Wageningen University \& Research and the author(s) of this publication shall not be held responsible or liable for any damages resulting from your (re)use of this publication.

For questions regarding the public availability of this article please contact openscience.library@,wur.nl 


\title{
Chapter 3 \\ Pectobacterium and Dickeya: Environment to Disease Development
}

\author{
Ian K. Toth, Marie-anne Barny, May B. Brurberg, Guy Condemine, \\ Robert Czajkowski, John G. Elphinstone, Valérie Helias, Steven B. Johnson, \\ Lucy N. Moleleki, Minna Pirhonen, Simeon Rossmann, Leah Tsror, \\ Jacquie E. van der Waals, Jan M. van der Wolf, Frédérique Van Gijsegem, \\ and Iris Yedidia
}

\begin{abstract}
The soft rot Pectobacteriaceae (SRP) infect a wide range of plants worldwide and cause economic damage to crops and ornamentals but can also colonize other plants as part of their natural life cycle. They are found in a variety of environmental niches, including water, soil and insects, where they may spread to susceptible plants and cause disease. In this chapter, we look in detail at the plants colonized
\end{abstract}

I. K. Toth (凶)

Cell and Molecular Sciences, James Hutton Institute, Invergowrie, Dundee DD2 5DA, UK

e-mail: ian.toth@hutton.ac.uk

M. Barny · F. Van Gijsegem

Sorbonne Université, INRAE, Paris, France

G. Condemine

Université de Lyon, CNRS, Villeurbanne, France

R. Czajkowski

University of Gdansk, IFB UG and MUG, Gdansk, Poland

J. G. Elphinstone

Fera Science Ltd, York, UK

V. Helias

FN3PT/inov3PT, Paris, France

S. B. Johnson

University of Maine, Maine, USA

L. N. Moleleki · J. E. van der Waals

University of Pretoria, Pretoria, South Africa

M. Pirhonen

University of Helsinki, Helsinki, Finland

M. B. Brurberg $\cdot$ S. Rossmann

NIBIO - Norwegian Institute of Bioeconomy Research, Ås, Norway

L. Tsror

Agricultural Research Organization, Gilat, Israel

J. M. van der Wolf

Wageningen University, Wageningen, the Netherlands

(c) Springer Nature Switzerland AG 2021

F. Van Gijsegem et al. (eds.), Plant Diseases Caused by Dickeya

and Pectobacterium Species, https://doi.org/10.1007/978-3-030-61459-1_3 
and infected by these pathogens and at the diseases and symptoms they cause. We also focus on where in the environment these organisms are found and their ability to survive and thrive there. Finally, we present evidence that SRP may assist the colonization of human enteric pathogens on plants, potentially implicating them in aspects of human/animal as well as plant health.

\subsection{Introduction}

Soft Rot Pectobacteriaceae (SRP) live on a wide range of plants and cause disease on many of them. Some SRP have wide host ranges, while others have only one known host, suggesting a degree of specialization. Unfortunately, many ornamentals and crops, including some of our main global staple crops, are affected by such diseases. While potato is particularly affected by SRP-associated diseases in terms of their economic damage, other plants see disease more sporadically but when it occurs it can be equally as damaging. Rice, maize, banana and other major crops are all affected but, thankfully, global annual losses are limited. Ornamental plants can be lost to disease but may also play a role in the spread of SRP to crops due to the large number of these plants that move around the world. The bacteria live in, and are spread from, a variety of environmental niches including soil, water and insects, with some species of SRP being found only in a particular environment with no evidence of a plant host, e.g. there have been five new species identified from water sources in the past year (Table 3.1). It is clear, therefore, that as we turn our focus away from plants, and especially diseased plants, there may be a much greater number of species in the environment than was originally thought, potentially with new capabilities that we know little about. Where SRP do cause disease in plants, the source and method of spread, process of infection and disease symptoms are surprisingly similar, leading to anything from minor disease through to large areas of cultivation being lost. The use of contaminated planting material and climate in any particular year are the main factors that determine this incidence and severity. SRP are also very closely related to enteric animal and human pathogens, which are known to live and even cause disease in plants. It is no surprise, therefore, that they can co-exist on plants, potentially competing against each other but also with the latter providing a rich supply of food for their counterparts. In this chapter, we discuss host range, infection pathways, disease progression and symptoms. We also investigate SRP in the wider environment and discuss the potential for many more species being present-a journey that we have only just begun. We will finish with a look at how SRP interact with animal and human enteric pathogens in an area that is so far little understood.

I. Yedidia

Agricultural Research Organization, Volcani Center, Israel 
Table 3.1 List of known plant hosts for current Dickeya and Pectobacterium species.

Dickeya

\section{D. aquatica}

Isolated from water, Daucus carota (1)

\section{D. chrysanthemi}

Agave cupreata (2), Chrysanthemum sp., Cichorium intybus (3), Euphorbia sp. (3),

Kalanchoesp. (3), Partheniumsp. (3), Solanum melongena (3) Vanda sp.

\section{D. dadantii subsp. dadantii and subsp. dieffenbachiae}

Amorphophallus konjac, Anubias barteri, Brassica rapa, Daucus carota (3), Euphorbia pulcherrima (12), Fragariasp. (3), Ipomoea batatas (3), Kalanchoesp. (3), Malus domestica (4), Malus pumila (5), Musa sp., Phalaenopsis aphrodite, Philodendron, Saintpaulia ionantha(6),

Solanum tuberosum (3), Tagetes patula, Vanilla planifolia, Zea mays (7)

\section{D. dianthicola}

Begonia bertinii (8), Chrysanthemum morifolium (8), Cichorium intybus, Cynara scolymus(9), Dahliasp. (8), Dianthus caryophyllus, Hyacinthus sp. (10), Kalanchoe sp., Lycopersicon esculentum (9), Sedumsp. (8), Solanum tuberosum

\section{D. fangzhongdai}

Aglonemasp. (3), Allium fistulosum (11), Artocarpus heterophyllus (13), Cattleyasp. (3), Clivia miniata (3), Colocasia esculenta (3), Dracaneasp. (3), Irissp. (3), Oncidiumsp. (3),

Phalaenopsissp. (14), Pyrussp. (15), Raphanus sativus (16), Vandasp. (3), Yuccasp. (3)

\section{D. lacustris}

Isolated from water; no known plant hosts (17)

\section{D. paradisiaca}

Musa sp., Solanum tuberosum (18)

\section{D. poaceiphila}

Megathyrsus maximus (19), Saccharum officinarum (19)

\section{D. solani}

Hyacinthus orientalis, Muscarisp. (20), Solanum tuberosum

\section{D. undicola}

Isolated from water; no known plant hosts (21)

\section{D. zeae/D. oryzae}

Ananas comosus (22), Asimina triloba (23), Calanthesp. (3), Canna edulis (24), Clivia miniata (23), Musa sp., Oryza sativa, Setariasp. (3), Solanum tuberosum (3), Zea mays

\section{Pectobacterium}

\section{P. aquaticum}

Isolated from water; no known plant hosts (24)

\section{P. actinidiae}

\section{Actinidia chinensis (25), Actinidia deliciosa}

\section{P. aroidearum}

Cucurbita pepo, Ornithogalum dubium, Persea americana, Saccharum, Solanum tuberosum, Zantedeschia aethiopica 
Table 3.1 (continued)

Dickeya

P. atrosepticum

Brassica rapa (26), Helianthus annuus, Solanum melongena, Solanum tuberosum, Zantedeschia aethiopica

\section{P. betavasculorum}

Beta vulgaris

\section{P. brasiliense}

Beta vulgaris, Brassica oleracea, Capsicum annuum, Citrullus lanatus (27), Cucumis sativus, Cucurbita pepo, Cynara cardunculus, Neobuxbaumia tetetzo (28), Nicotiana tabacum, Raphanus sativus (29), Solanum lycopersicum, Solanum tuberosum

\section{P. cacticida}

Carnegiea gigantea, Helianthus annuus

\section{P. carotovorum}

Abelmoschus esculentus, Allium sativum (30), Artemisia absinthium, Brassica oleracea, Cichorium intybus, Citrellus lanatus, Cucumis sativus, Cynara cardunculus, Daucus carota (1), Echonipsis chamaecereus (syn. Chamaecereus silvestrii), Fritillaria imperialis, Hawthoria, Ipomoea batatas, Kalanchoe tubiflora, Lactuca sativa, Musasp. (31), Opuntia sp., Orostachys japonica, Orostachys malacophylla, Papaver somniferum, Peperomia obtusifolia, Peperomia caperata, Plectranthus australis, Pilea cadierei, Pinellia ternata, Rheum rhabarbarum, Silybum marianum, Saintpaulia ionantha, Solanum lycopersicum, Solanum melongena (32), Solanum tuberosum, Spathiphyllum wallisii, Typhonium giganteum

\section{P. fontis}

Isolated from water; no known plant hosts $(\underline{33)}$

\section{P. odoriferum}

Allium ampeloprasum, Allium cepa, Apium graveolens, Brassica oleracea, Brassica rapa, Cichorium endivia, Cichorium intybus, Daucus carota, Ipomoea batatas, Petroselinum crispum

\section{P. parmentieri}

Solanum tuberosum

\section{P. parvum}

Solanum tuberosum (34)

\section{P. peruviense}

$\underline{\text { Solanum tuberosum (35) }}$

P. polaris

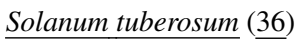

\section{P. polonicum}

Groundwater from a vegetable field (37)

\section{P. punjabense}

$\underline{\text { Solanum tuberosum (38) }}$

\section{$P$. versatile}


Table 3.1 (continued)

Dickeya

Allium porrom (39), Brassica oleara (39), Cichorium intybus (39), Cynara scolymus (39), Chrysanthemumsp. (39), Cyclamensp. (39), Daucus carota (39), Hyacinthus orientalis (39), Irissp. (39), Lactuca sativa (39), Primulasp. (39), Solanum tuberosum (39)

P. wasabiae

Brassica oleracea $^{\mathrm{a}},{\text { Eutrema japonicum, Ipomoea } \text { batatas }^{\mathrm{a}} \text {, Solanum lycopersicum }}^{\mathrm{a}}$, Solanum melongena

\section{P. zantedeschiae}

Zantedeschiaesp. (40)

Data from Charkowski (2018) with additional names underlined and corresponding references as follows: (1) Zaczek-Moczydlowska et al. 2019, (2) Cabrera-Huerta et al. 2019, (3) Suharjo et al. 2014), (12) Wei et al. 2018, (4) Fujikawa et al. 2019, (5) Ogoshi et al. 2019, (6) Boccara et al. 1991, (7) Askari et al. 2018, (8) Parkinson et al. 2009, (9) Samson et al. 2005, (10) van Doorn et al. 2011, (11) Tsai et al. 2019, (12) Jaffar et al. 2019, (13) Alič et al. 2018, (14) Tian et al. 2016, (15) ncbi, microbial genomes, (16) Hugouvieux-Cotte-Pattat et al. 2019, (17) Hugouvieux-Cotte-Pattat et al. 2020, (18) Pritchard et al. 2013, (19) Khayi et al. 2015, (20) Oulghazi et al. 2019a, (21) Nor et al. 2019, (22) Yang et al. 2018, (23) Hu et al. 2018, (24) Pédron et al. 2019, (25) Yan et al. 2019, (26) Sadeghi-Seraji et al. 2018, (27) Zlatkovic et al. 2019, (28) Mejia-Sanchez et al. 2019, (29) Liu et al. 2019, (30) Xie et al. 2018, (31) Basim et al. 2019, (32) Huang et al. 2017, (33) Oulghazi et al. 2019b, (34) Pasanen et al. 2020, (35) Waleron et al. 2018, (36) Dees et al. 2017, (37) Waleron et al. 2019a, (38) Sarfraz et al. 2018, (39) Portier et al. 2019, (40) Waleron et al. 2019b.

${ }^{\text {a }}$ may be $P$. parmentieri

\subsection{Plant Hosts of Soft Rot Pectobacteriaceae}

SRP are broad host range pathogens able to colonize and sometimes infect a wide range of plant species, from potato to carnation, and are present in all climatic zones where plants are cultivated (Pérombelon 1988; Charkowski 2006). Although it is largely acknowledged that potatoes are the most economically important crop affected by SRP, these bacteria are also found on many other plants including other crops, ornamentals, weeds/wild plants and plant debris, across at least $35 \%$ of angiosperm plant orders, as well as in irrigation and surface water, aerosols, insects and on contaminated tools and equipment (Charkowski 2018; Ma et al. 2007; Pérombelon 2002). When not causing disease, the bacteria live largely unnoticed on plants and in these different environments (Pérombelon and Hyman 1989; Ma et al. 2007; Toth et al. 2011). However, where disease is present it appears to affect mainly vegetables and ornamental plants, although other more economically important crops are affected, e.g. maize, rice, date palm and banana (Charkowski 2018). A detailed list of plant hosts is given in Table 3.1 (updated from Charkowski 2018), with some described in further detail below.

From Table 3.1, it can be seen that while some SRP have a wide host range, e.g. D. dadantii, D. dianthicola, D. fangzhongdai, $P$. brasiliense, $P$. carotovorum, $P$. odoriferum and $P$. versatile, others appear to have a much narrower one, e.g. $D$. paradisiaca and $D$. actinidiae, with some having only a single known host, e.g. 
D. aquatica (Daucus carota-carrot), P. betavasculorum (Beta vulgaris), P. zantedeschiae (Zantadeschia sp.) and P. parmentieri, P. parvum, P. peruviense, P. polaris and $P$. punjabense (Solanum tuberosum - potato), with a final group having no known plant hosts, e.g. D. lacustris, D. undicola, $P$. aquaticum, $P$. polonicum and $P$. fontis (all water-associated). Interestingly, species with only potato as a host have all been named within the last 4 years, and those with no known host in the last year. This suggests a recent focus towards research on potato or water sources using new molecular methods of taxonomic identification (See Chap. 2). In time, new plant hosts for these water-associated species may be uncovered. For example, D. aquatica was identified only from water sources when originally published (Parkinson et al. 2014a) but was later found to infect carrot (Zaczek-Moczydlowska et al. 2019). Table 3.1 thus offers what is almost certainly an incomplete view of potential host plants for the different Dickeya and Pectobacterium spp. based on the limited number of plant species tested.

\subsubsection{Potato and Other Solanaceae Plants}

SRP infect a wide range of crops, especially those with soft flesh. While potato is economically the most important (see Chap. 8), other crops include chicory, carrot, eggplant (aubergine), maize, rice, sweet potato, date palm, tomato, tobacco, and brassica crops such as bok choy, Brussel sprouts, cabbage, cauliflower, Chinese cabbage, kale and turnip, along with fruits including apple, pear, strawberry, water melon, banana and Sharon fruit (Table 3.1). These infections are observed in most countries of the world (see Chap. 7).

Potato (a member of the genus Solanum - the most commonly cultivated species of which is $S$. tuberosum) is the most notable crop due to its production volume (368 M tonnes from 17.5 M hectares-FAOSTAT 2018) and its importance as a staple crop in many countries, combined with the extent of losses caused by SRPrelated diseases. The ability of SRP to infect potato is therefore covered in detail throughout this book. Potato cultivation in China, Africa and elsewhere is expanding rapidly, especially in low income food deficient countries (a doubling of production over the last 20 years) with a global increase in production intensity on a decreasing area of land (FAOSTAT 2018). It is highly likely, therefore, that soft rot and blackleg diseases of potato will increase significantly in the future with associated economic losses. An example of the economic consequences of SRP on potato in Switzerland and extrapolation to the European Union is given in Chap. 8.

In addition to potato, SRP have been shown to cause disease on other Solanum spp. including tomato (Solanum lycopersicum) and eggplant (Solanum melongena) but have also been repeatedly isolated from symptomless Solanum dulcamara plants (a wild species with preference for wetlands) from natural habitats associated with potato production. $S$. dulcamara could therefore act as a reservoir for contamination of potato. Olsson (1985) reported the isolation of Dickeya spp. from symptomless $S$. dulcamara growing in a watercourse used for irrigation in Sweden (Olsson 1985). 
Fikowicz-Krosko et al. (2017) reported $P$. carotovorum isolated from symptomless roots of $S$. dulcamara growing in a potato cultivation region in northern Poland. Similarly, D. dianthicola was found to infect $S$. dulcamara under glasshouse conditions, with only minor symptoms observed (Elphinstone 2008). However, FikowiczKrosko and Czajkowski (2018) recently reported the development of disease symptoms and systemic colonization of $S$. dulcamara plants (in culture tubes) inoculated with $D$. solani, similar to those observed on in vitro cultivated potato plants. In contrast, $S$. dulcamara plants grown in potting compost in a growth chamber did not develop symptoms after stem stab-inoculation with $D$. solani despite the relatively high inoculum of $10^{5} \mathrm{cfu}$ per inoculation point (Fikowicz-Krosko and Czajkowski 2017). This may further indicate that although SRP are able to colonize S. dulcamara, they may encounter problems in establishing infections.

\subsubsection{Other Crops}

Other crops infected by SRP include a wide range of fruit and vegetables with rice, maize and banana, together with potato, representing some of the world's most highly grown crops (FAOSTAT 2018). Bacterial stork rot and top rot are diseases of maize in tropical and subtropical countries, including Iran (D. dadantii), India, Mexico, Pakistan and the USA (D. zeae) and, like other soft rot diseases in these regions, they are particularly severe under high temperature and humidity conditions (Ahmed et al. 2000; Askari et al. 2018; Kumar et al. 2017; Lopez et al. 1986; Martinez-Cisneros et al. 2014). For example, a serious outbreak in Iran led to up to $50 \%$ of plants in the diseased area being severely affected (Askari et al. 2018). Foot rot of rice, caused by D. zeae, was first reported in the 1970s in Japan and affects rice quality and yield (Goto 1979), with an increase in outbreaks more recently in Southeast Asia and Southern China, possibly due to changes in rice cultivation methods and climatic conditions (Liu et al. 2013; Pu et al. 2012). One of the most effective methods to control the disease in rice is the use of resistant varieties (Sect. 6.6; Li et al. 2018a). A recent study recognized two clades within D. zeae strains (Pédron and Van Gijsegem 2019), one of which has been renamed $D$. oryzae following reanalysis of rice strains (Wang et al. 2020). Banana is globally the most widely grown fruit and has a production of $116 \mathrm{M}$ tonnes, rising six-fold in the last 60 years (FAO 2018). It is produced in over 150 countries worldwide with half the production in Asia. Outbreaks of soft rot disease in banana continue to cause substantial economic losses in China (D. zeaeZhang et al. 2014), across South and Central America (D. paradisiaca-Blomme et al. 2017) and other countries including Korea, Iran, Turkey (P. carotovorum Basim et al. 2019; Chio et al. 1988; Hassanzadeh 1990; Snehalatharani et al. 2010), and India (D. paradisiaca and P. carotovorum - Chattopadhyay et al. 1986; Gokul et al. 2019). For example, in 2009 a bacterial soft rot outbreak in China caused by D. zeae resulted in up to $82 \%$ yield loss in the infected area, with a subsequent increase in incidence and severity to 6000 ha in 2012. Disease incidence ranged from $20-70 \%$ and up to $90 \%$ in some cases, with infected plants dying one week 
after the appearance of symptoms. The importance of seedling quarantine has been identified as a major route to disease reduction, in a similar way to that of potato and other crops (Arun et al. 2012; Zhang et al. 2014). There is a relatively small amount of research on the above diseases in rice, maize and banana etc., especially given the high global production of these crops. This suggests that, while losses are potentially high for any given outbreak, they may have relatively minor economic impact globally compared to other pests and diseases of these crops or of SRP on potato.

\subsubsection{Ornamental Plants}

Soft rot disease by SRP in ornamental crops occurs mostly in herbaceous perennial geophytes (plants with underground storage organs) also known as flower bulbs. There are no reports of the disease in woody ornamentals. Ornamental geophytes are often characterized by fleshy organs such as leaves or petioles and a carbohydrate rich underground storage organ, i.e. a corm, tuber, rhizome or bulb that contains renewal buds located underground. In most cases, the typical ornamental SRP strains display a wide host range, overlapping hosts and have a wide geographical distribution (Charkowski 2018; Ma et al. 2007; Yishay et al. 2008). Other bacterial genera, such as Bacillus, Burkholderia, Clostridia, Enterobacter and Pseudomonas may also cause soft rot symptoms in storage organs of bulbous plants (Charkowski 2018; Dahaghin and Shams-Bakhsh 2014). Several hosts of soft rot disease are eudicot plants that hold storage organs or fleshy leaves, including Begonia, Cyclamen, Dahlia, Kalanchoe, Pelargonium, Primula and Saintpaulia (Dahaghin and Shams-Bakhsh 2014; O'Neill et al. 2012; Table 3.1). Other eudicot genera are Chrysanthemum and Dianthus (carnation) both of which are members of the top 5 most sold flowers, with various cultivars worldwide (Hanks 2018). These are frequently reported as hosts of Dickeya spp. and mainly D. chrysanthemi, D. dadantii and D. dianthicola (Charkowski 2018; Ma et al. 2007; Table 3.1). Another group of hosts include the families Asphodelaceae, Agavaceae, and Cactaceae, with fleshy species of Agave, Aloe vera and cacti such as Acanthocereus, Chamacererus and Schlumbergera often reported as hosts of $P$. carotovorum (Dahaghin and Shams-Bakhsh 2014; Ma et al. 2007). The most significant group of plant hosts of SRP are monocot bulb crops, which are traded as cut flowers, garden plants and potted plants. Several examples are Clivia, Crinum, Crocus, Freesia, Fritillaria, Gladiolus, Hosta, Hyacinthus, Iris, Lilium, Ornithogalum, Tulipa and Zantedeschia. Highly susceptible plants from this group belong to the family Araceae and include Aglaonema, Dieffenbachia, Philodenderon, Scindapsus, Spathiphyllum, Syngonium as well as Zantedeschia, all with high commercial importance as potted and garden plants, and mostly mentioned as hosts of SRP (Dahaghin and Shams-Bakhsh 2014; Ma et al. 2007; Table 3.1). Since many reports concerning ornamental hosts are from 1950-2000, several misidentified strains and species probably exist for both soft rot genera. 
In Europe, D. dianthicola was first recorded as causing slow wilting and stunting on Dianthus in the Netherlands, UK and Denmark but has since appeared in other European nations (EFSA Scientific Opinion 2013). It was estimated that in 1958 $26.2 \%$ of carnation stocks in Denmark were affected by the disease (Hellmers 1958). D. dianthicola was thereafter listed as a quarantine organism on Dianthus (Council Directive 2000/29/EC) but damage has been limited in recent years due to strict glasshouse hygiene and certification of plant material (Toth et al. 2011). Janse and Ruissen (1988) suggested a degree of host specialisation for D. dianthicola strains involved in infection, as a strain isolated from Dianthus (NCPPB 453) was unable to cause symptoms in Kalanchoe. Although Dickeya spp. have been detected on a wide range of ornamental plants in Europe, only D. dianthicola and D. solani have also been found to infect potato, fuelling speculation that some Dickeya strains may have spread to potato from ornamental host plants. For example, D. solani strains isolated from potato in multiple countries were found to be closely related to a Dutch strain from Hyacinthus, while VNTR profiles within D. dianthicola and D. solani isolates from ornamentals and potato revealed common profiles between hosts (Parkinson et al. 2014b ; Toth et al. 2011; van der Wolf et al. 2014). While import of potatoes into Europe is controlled, the import of ornamentals is less closely regulated with the entry of many millions of plants for planting, e.g. in 2010 the Netherlands, Germany, Italy and France imported $160 \mathrm{M}$ units of Kalanchoe, $53 \mathrm{M}$ Begonia and $27 \mathrm{M}$ Dahlia (EFSA Scientific Opinion). As some ornamental plants are grown in fields in rotation with potato, whether in Europe or elsewhere in the world, this could aid transmission to or from potato and potentially other crops (Parkinson et al. 2014b).

Pectobacterium spp., while causing disease on ornamental plants, show different host specialization, with $P$. zantedeschiae appearing to specialise on its host plant Zantedeschia, while $P$. carotovorum and other species have a wider host range on ornamental and other plants (Table 3.1). Atypical strains of P. carotovorum with a preference for monocot plants have been reported from several herbaceous monocot hosts including Allium sativum (Smith and Bartz 1990; Wright 1998; Seo et al. 2002), Zantedeschia sp. (Smith and Bartz 1990; Byther and Chastagner 1993; Wright 1998; Snijder and van Tuyl 2002; Wang et al. 2018), Dieffenbachia sp., Scindapsus aureus (Norman et al. 2003), Ornithogalum sp. (Ma et al. 2007), Fritillaria imperialis (Mahmoudi et al. 2007) and Pinellia ternate (Ying et al. 2007), where they have been shown to cause disease (Smith and Bartz 1990; Ying et al. 2007). A wide phylogenetic study suggested that these isolates (represented by an isolate from Ornithogalum dubium Ec106) were members of a larger "monocot clade", as they did not cluster with typical $P$. carotovorum strains (Ma et al. 2007). Isolates from the aroid houseplant Syngonium podophyllum and bulbs of Iris sp., also grouped with the isolate Ec 106 from Ornithogalum (Baghaee-Ravari et al. 2011). A survey carried out in Israel in commercial plots of Zantedeschia and Ornithogalum showed that about $80 \%$ of the isolates displayed "monocot clade" characteristics. Testing a larger number of isolates from monocot hosts from several geographical locations, using internally transcribed spacer-PCR, 16S rRNA gene sequence analysis and AFLP, revealed that these isolates cluster together independently of their geographical origin (Yedidia et al. 2011). Finally, based on a large collection of representative Pectobacterium 
strains, AFLP and MLSA phylogenies clustered most isolates from monocot hosts together in a unique cluster (cluster Pc V) (Nabhan et al. 2012). This cluster includes the strains SCRI109 ${ }^{\mathrm{T}}$, SCRI121, SCRI3, SCRI102 and Pc1, three of which were initially identified as 'Erwinia aroideae' by Townsend in 1904 describing soft rot bacteria from arum (Zantedeschia sp.) in the family Araceae (Nabhan et al. 2013). Accordingly, $P$. aroidearum was suggested and is now accepted as a new species, which mainly but not exclusively causes soft rot diseases on monocot hosts (Nabhan et al. 2013).

Soft rot is an economically damaging disease of orchids and was first reported on Dendrobium and Phalaenopsis sp. in South Korea (Lee et al. 1999). Soft rot disease of orchids is a major disease problem of Phalaenopsis in Florida (McMillan et al. 2007), with symptoms including macerated, brown and water-soaked leaves (Cating et al. 2008). It has also been found worldwide on other orchid species including Vanda, Oncidium and Tolumnia, with Dickeya spp. identified as the causal agent (Cating et al. 2009, 2010; Li et al. 2009). For example, Lin et al. (2015) showed that Dickeya spp. and not Pectobacterium spp. were the dominant soft rot pathogens of Onicidium orchid. Detached leaf assays have been developed for testing germplasm and progeny resistance in various orchid breeding programmes (Sudarsono et al. 2018). Recently, Dickeya spp. isolated from orchid, water and pears were identified as a new species following genomic analysis and named $D$. fangzhongdai. The first genomes of Dickeya isolates from orchid were sequenced in 2015 (Alic et al. 2015). However, later sequencing of $D$. fangzhongdai isolates revealed that the species represents typical orchid-associated strains and is phylogenetically similar to $D$. solani and $D$. dadantii but lacks the Stt Type II secretion system of $D$. dadantii (Zhang et al. 2018). The authors found that only orchid-associated strains were able to cause soft rot on orchids when reinoculated, suggesting a degree of host specificity.

\subsubsection{Weeds Present Near Potato Production Areas}

The survival of SRP on weeds has been recognized since the late 1960s (Burr and Schroth 1977; Kikumoto and Sakamoto 1969), and in more recent decades SRP strains have been isolated successfully from various weed and crop plants, including their consistent isolation from the rhizosphere of brassica plants (Burr and Schroth 1977; Gudmestad and Secor 1983; Pérombelon and Hyman 1989; Toth et al. 2015; Tsror et al. 2011; Zoledowska et al. 2018). Over 24 and 47 plant species in Colorado and Scotland, respectively, taken from both potato fields and fields with a history of potatoes, were found to be colonized mainly with $P$. carotovorum but also in some cases with $P$. atrosepticum. Weeds from virgin land (no history of potatoes) in Scotland but not Colorado were also found to yield P. carotovorum in some cases. Contamination increased as the season progressed to its highest in summer and appeared to be linked to temperature and moisture conditions (McCarter-Zorner et al. 1984, 1985). 
In more recent surveys in Israel, symptomless plants of 12 species (Cyperus rotundus, Orobanche aegyptiaca, Amaranthus spinosus, Polygonum equisetiforme, Chenopodium sp., Heliotropium sp., Centaurea iberica, Sorghum haepense, Malva nicaeensis, Cynodon dactylon, Amaranthus blitum and Solanum elaeagnifolium) were collected from potato fields where Dickeya-infected potato plants were detected. D. solani was isolated only from $C$. rotundus, with 6.7 and $14.3 \%$ of plants harboring the pathogen in 2009 and 2010, respectively (Tsror et al. 2011). In a more recent survey again in Israel, symptomless weed plants from 12 genera and 9 families (Polygonum equisetiforme (Polygonaceae), Centaurea procurrens, Sonchus oleraceus (Asteraceae), Lolium rigidum, Phalaris brachystachys, Avena sterilis (Poaceae), Malva nicaeensis (Malvaceae), Amaranthus blitoides (Amaranthaceae), Chenopodium murale (Chenopodiaceae), Chrozophora tinctoria (Euphorbiaceae), Orobanche aegyptiaca (Orobanchaceae), Erucaria rostrate (Brassicaceae)) were collected from potato fields where Pectobacterium- and Dickeya-infected plants were detected. Only Malva nicaeensis was found to be latently infected (with $P$. brasiliense) (Tsror et al. 2019). Weeds, although unspecified, from potato fields throughout Poland were found to harbor P. parmentieri that were indistinct from those on potato plants and tubers (Zoledowska et al. 2018). Similarly, Toth et al. (2015) also identified that $P$. atrosepticum was able to bind to unspecified weed species with similar efficiency to that on potato roots but that subsequent colonization was plant species dependent. They concluded that weeds, and potentially other crops, may be potential sources of contamination to potatoes in the field.

\subsection{Environmental Niches, Survival and Dispersal of SRP in the Environment}

Plants can become colonised/contaminated with SRP from a variety of environmental sources, e.g. in the case of potato from soil, aerosols, irrigation, rainwater and insects (Pérombelon and Salmond 1995). Recent research on SRP in environmental niches has used modern taxonomic methods to determine the species present (see below). However, in earlier studies characterizations of the isolates consisted mostly of biochemical and serological analyses, where most strains were classified as Erwinia carotovora subsp. carotovora or Erwinia chrysanthemi, indicating that isolates belonged simply to the present Pectobacterium or Dickeya genera. Serological analysis performed in these early works identified up to 21 serogroups, and a significant proportion of the isolates did not belong to known serogroups, pointing out the wide diversity of these isolates (Cappaert et al. 1988; Peltzer and Sivasithamparam 1988; Powelson and Apple 1984). Unfortunately, most of the strains isolated in nonhost environments in these studies were not deposited in international collections. A survey of five international collections performed in 2018 indicated that amongst the 1293 Pectobacterium and Dickeya strains available, only 17 were isolated from non-host environments. Out of these 17 strains, twelve were isolated from water, 
four from soils and one from plant-derived food. It is not possible therefore to assess today the taxonomic status of the strains isolated in these early studies and the extent to which species are presence away from plants remains an unanswered question. To overcome this issue, it is recommended that resampling is carried out in non-host environments to understand the full extent of SRP species present. Ideally, sampling would be extended to countries from different geographic regions and with different climates. Indeed, early studies were generally performed in a temperate region, but the relative proportion of the different species is likely to vary with climate. While water and soil are perhaps the most obvious environments for sampling, as SRP are known to be found there, it is possible that other environments, which have been much less or never studied, could also act as reservoirs of SRP, e.g. Pseudomonas syringae has been found in snow, alpine streams and lakes, and epilithic (attached to gravel and stone) river biofilms (Morris et al. 2013).

\subsubsection{Soft Rot Pectobacteriaceae in Water}

SRP have been identified in waterways globally, including in Australia, Finland, France, Malaisia, Poland, UK, Spain, Switzerland, and USA (Cahill et al. 2010; Hugouvieux Cotte Pattat et al. 2019; McCarter-Zorner et al. 1984; Harrison et al. 1987; Laurila et al. 2008; Laurila et al. 2010; Oulghazi et al. 2019a, 2019b; PalacioBielsa et al. 2010; Parkinson et al. 2014a; Pédron et al. 2019; Potrykus et al. 2016; Sueno et al. 2014; Waleron et al. 2019b). Surveys were performed both next to crop species/weeds but also in pristine alpine water or moorland, and positive samples were found even in areas remote from arable land, indicating a large circulation of these species. However, the frequency of detection tended to increase in rivers close to arable land, suggesting that irrigation water can serve as a potential source of inoculum for SRP species. Numerous reports have pointed to the contamination of surface water by SRP (Cappaert et al. 1988; Gudmestad and Secor 1983; McCarter-Zorner et al. 1984; Peltzer and Sivasithamparam 1988) and the potential contamination of plants via water reservoirs (Franc and Harrison 1987).

The presence of Pectobacterium spp. in surface water has been well documented in studies testing water from different sources, geographical locations and climates. Pectobacterium spp. have been isolated from winter snow in the mountains, a waterfall, rain, river, sea-, well- and ground-water and they are thus considered ubiquitous in nature (Pédron et al. 2019; McCarter-Zorner et al. 1984; Harrison et al. 1987; Maddox and Harrison 1988; Waleron 2019b). Sea water is considered as a reservoir from which Pectobacterium spp. are spread into the air as aerosols that are formed through the action of waves (Pérombelon and Kelman 1980). The bacteria are also thought to spread in the air as aerosols formed during rain splash, sprinkler irrigation and mechanical pulverization. These aerosols may play a role in spread of the bacteria to clean mini-tubers, which can be contaminated by SRP during the first field generation (Graham et al. 1979; Elphinstone and Pérombelon 1987). 
Very early reports allude to the fact that infection of plants can occur via irrigation with contaminated water (Cappaert and Powelson 1987; Franc and Harrison 1987). Later studies focused on test water sources for the presence of SRP and the role that irrigation water plays in dissemination of these pathogens. For example, McCarterZorner et al. (1984) tested surface water in southern Scotland and Colorado and, from 572 water samples tested, 439 were positive for pectinolytic bacteria; $95 \%$ being classified as Pectobacterium spp. and $9.8 \%$ as P. atrosepticum. Similar results were obtained by Jorge and Harrison (1986), Maddox and Harrison (1988) and Pérombelon and Hyman (1987) who showed the predominance of Pectobacterium spp. (80\% compared to $99 \%$ ) and P. atrosepticum specifically (20\% compared to $1 \%$ ) in surface water in northern Colorado and eastern Scotland, respectively. In Oregon and Colorado, isolations from surface irrigation water and well water in 1985 and 1986 also commonly yielded Pectobacterium spp., followed by Dickeya spp. as the second most isolated SRP, although $P$. atrosepticum was rarely isolated (Cappaert et al. 1988). Furthermore, out of the 1436 strains isolated only $30 \%$ could be characterized by serology, illustrating the great diversity of isolates obtained. In Australia and Finland, river surveys identified Dickeya spp. as the dominant genus at the time of the study (Cother and Gilbert 1990; Laurila et al. 2008). In the Australian survey, all positive samples were from water with a temperature above $16.2{ }^{\circ} \mathrm{C}$ (a climate where Dickeya spp. are more likely to be present on plants), which may explain why they were dominant in these samples compared to Pectobacterium spp. that have a lower optimal temperature (du Raan et al. 2016). Serological analysis of the 56 Australian isolates differentiated the Dickeya isolates into two serogroups representing the two Australian rivers sampled (Cother et al. 1992). The Finnish survey showed three distinct bacterial clades following analysis of $16 \mathrm{~S}$ and $16 \mathrm{~S}-23 \mathrm{~S}$ sequences of the 24 Dickeya isolates, two of which were different from previously isolated Dickeya spp., while the third clade corresponded to D. dianthicola. Water isolates of $D$. dianthicola appeared to be more aggressive than those isolated from diseased potato plants (Laurila et al. 2008). These results again point to the large diversity of SRP isolates from water and their varying geographical distribution.

Populations of bacteria in water were shown to peak in mid- to late summer in Oregon and Colorado in the USA and in Scotland, coinciding with lush crop canopy growth and a conducive micro-climate for epiphytic growth and survival of bacteria (Jorge and Harrison 1986; Pérombelon and Hyman 1987; Cappaert and Powelson 1987). It is possible that with successive irrigation events during the summer months the numbers of bacteria on plants increase, leading to disease (Cappaert and Powelson 1987). In contrast, there was no seasonal variation in populations of SRP found in water sources in Florida, although strains of both Dickeya and Pectobacterium spp. were isolated from nursery retention ponds and lakes (Norman et al. 2003). The authors attributed this to a mild winter climate, drought during the sampling period, the nutrient-rich nature of the sampled water or the year-round cropping cycle in Florida (Norman et al. 2003). The levels of SRP in nursery retention ponds were higher than in natural lakes, indicating the possible role of recycled irrigation water in contamination of water sources (Norman et al. 2003). Armon et al. (1995) also warned of the risk of irrigation with reused water or water sources with high nitrate content, 
as these sources may sustain the survival of SRP and in some cases allow regrowth of the bacteria. van Doorn et al. (2011) showed that Dickeya spp. survived poorly in rain and ditch water (surviving for only a few hours) compare to P. atrosepticum and $P$. carotovorum, both of which survived with little loss of viability for over 150 days. In tap water, Dickeya spp. also survived poorly but the Pectobacterium spp. also only survived for ca 2 days, presumably due to chemical treatment of the water. Recently, two strains belonging to the recently named $P$. peruviense species were isolated from river samples in France (Faye et al. 2018) indicating that "P. peruviense" has a wider geographic distribution than the Peruvian altiplano (Waleron et al. 2018).

Compared to Pectobacterium spp., Dickeya spp. are less commonly isolated from water. To understand which particular Dickeya spp. are recovered from water, detection of Dickeya positive samples was achieved through dedicated PCR screening of 7902 water samples from rivers, lakes, ponds and drainage ditches in Poland (Potrykus et al. 2016) and 230 samples from water courses in Scotland (Cahill et al. 2010). Overall Dickeya spp. detection was low (1.7\% of the Polish samples and $0.36 \%$ of the Scottish samples), and in both countries D. zeae was the most abundant species recovered, followed by $D$. chrysanthemi in Polish samples. Among the Scottish samples, an undefined Dickeya sp. was also recovered together with a single finding of $D$. solani. The detection and positive identification of this latter species, coupled with its increased impact on potato production in other European countries and Israel (Laurila et al. 2008; Tsror et al. 2009, Sławiak et al. 2009), highlights the importance of careful and ongoing water surveys. A more recent PCR screening for Dickeya spp. in Hawaiian irrigation water, using REP-PCR, identified a new clade that grouped most of the strains isolated from water. This suggests the presence of natural genetically distinct populations of water-borne Dickeya spp. (Sueno et al. 2014) that may not be directly related to strains causing disease on crops but could be from plant hosts not yet identified.

Several new species of Pectobacterium and Dickeya have recently been described following isolation from water. Dickeya species include D. aquatica, D. lacustris and D. undicola: D. aquatica was isolated from rivers in Finland and Scotland and showed low pathogenicity in potato field trials (Parkinson et al. 2014a, b; Laurila et al. 2010). D. lacustris, which is closely related to D. aquatica, was isolated from nutrient-rich lakes in France, although the behaviour of $D$. lacustris strains on plants is still unknown (Hugouvieux Cotte-Pattat et al. 2019). D. undicola was isolated from freshwater samples in both Asia and Europe (Oulghazi et al. 2019a). Pectobacterium species isolated from water include P. aquaticum, P. fontis and P. polonicum: $P$. aquaticum was isolated from rivers in France and can rot potato slices but their virulence on plants has yet to be determined, while its closest relative using ANI/dDDH analyses is $P$. carotovorum (Pédron et al. 2019). P. fontis is a new species isolated from a waterfall in Malaysia (Oulghazi et al. 2019b) representing a novel clade that is distinct from other Pectobacterium spp. Virulence assays on potato tubers showed that $P$. fontis was able to induce a weaker decay on potato tubers than other Pectobacterium spp. such as $P$. parmentieri and $P$. brasiliense. P. polonicum was isolated from groundwater from a vegetable field in Poland and found to be a new species using is $\mathrm{DDH}$ and $\mathrm{ANI}$ analyses. Its closest relatives are $P$. punjabense, . parmentieri and 
P. wasabiae (Waleron et al. 2019b). Of these new species, only D. aquatica has so far also been found on plants; carrot (Daucus carota) (Zaczek-Moczydlowska et al. 2019). As stated above, whether this increase in water-specific species is due to more recent and intense analyses of water sources or whether it is due to improvements in taxonomic methods, and ultimately these species will also be found on nearby plants, remains to be seen.

The levels and species of bacteria found in water are likely to be affected by climate, geographical region and land use surrounding water sources. According to Cother et al. (1992), water can be considered part of the continuum of diverse environments that support the growth and survival of SRP. In future studies, systematic measurements during water sampling could include more information on water temperature, nutrients (including organic matter) and a description of the uses of surrounding land, to help to better understand the distribution of particular species in a given water source environment. This work, coupled with precise taxonomic characterization and determination of known SRP detected in water sources used for irrigation, is necessary to better characterize the risks associated with SRP circulation in irrigation water (Kastelein et al. 2020).

\subsubsection{Soft Rot Pectobacteriaceae in Soil}

Data on the survival of SRP in naturally infested substrates is restricted due to a limitation in the detection thresholds for soil (De Boer et al. 1979; Meneley and Stanghellini 1976). Nevertheless, SRP populations are often detected following potato planting, but then rapidly disappear over winter to very low levels. SRP have also been detected, albeit at low frequency, in fields in the absence of potato regardless of their cropping history, suggesting that SRP may be endemic in the tested soils and possibly therefore the plants growing in those soils (Pérombelon and Hyman 1989). Detection of SRP in soil is not only hampered by the detection threshold of the assays, but likely also by the heterogeneous distribution of SRP in soil, although solid data on this are lacking. In addition, direct methods such as DNA-based amplification and ELISA will detect dead bacterial cells resulting in an overestimation of the risks for infection. To improve the diagnostic sensitivity of assays, incubation of soil samples in a broth under low oxygen conditions can be done, which allows multiplication of SRP and enhances the probability of detecting and isolating the target bacteria (Peltzer and Sivasithamparam 1988; Powelson and Apple 1984). The efficiency of cultivation-based techniques, however, can be affected by the high microbial background in the soil that interferes with the growth of SRP. Enrichment negatively affects the possibilities of quantifying bacterial densities in soil.

An unresolved issue remains the detection of low densities of cells that may exist in soil in a viable but non culturable (VBNC) state (Gorshkov et al. 2009). A VBNC state was artificially induced using copper sulphate in $D$. dianthicola, with at least $90 \%$ of cells tested entering the VBNC state and remaining so for 2 months at $28{ }^{\circ} \mathrm{C}$ (the length of the study). This suggests that this state may help to protect the bacteria 
from application of copper products in seed treatments and may also assist survival through the winter months (Ge et al. 2017).

Although it is possible that SRP exist in soils in the absence of crop residues, most isolations appear to be from soils in which host crops have been grown (Burr and Schroth 1977; Powelson and Apple 1984). Bacteria detected in soil are probably associated with the rhizosphere of (perennial) weeds and crop debris (Burr and Schroth 1977; Gudmestad and Secor 1983; McCarter Zorner et al. 1985) or as a result of decaying plant material (Lapwood and Harris 1982). In Scotland, survival was best in the rhizosphere soil of Brassicaceae, moderate in soil of grasses and cereals, and least on soil of certain weeds and (surprisingly) potato (Pérombelon and Hyman 1989). However, in the USA in spring, SRP were detected more frequently from soils in which potato was planted in the previous year than other crops such as bean and maize, indicating an influence of crop rotation schemes on soil infestation (De Boer et al. 1979). In Australia in spring, $25 \%$ of all soil samples taken from fields the year before potatoes were planted, were contaminated with SRP including $93 \%$ P. carotovorum, $5.6 \%$ P. atrosepticum, and $1.9 \%$ Dickeya spp. (Peltzer and Sivasithamparam 1988).

Pectobacterium spp. appear to survive better in soils than Dickeya spp. In general, P. carotovorum is more frequently found in soil than P. atrosepticum and Dickeya spp., e.g. in studies in Scotland P. carotovorum predominated (91 \%) (Pérombelon and Hyman 1989). Studies in the Netherlands showed that Dickeya isolates from potato and hyacinth could not survive for more than seven days when added to different soils at $6{ }^{\circ} \mathrm{C}$ and $50 \%$ field moisture capacity, compared with 42 days for Pectobacterium isolates (Van der Wolf et al. 2009).

Survival in soil depends on numerous biotic and abiotic factors in an environment that in general will be hostile to the pathogen in the absence of plant material. In sterilized soil there is a prolonged survival of SRP indicating a negative effect of other microbes in the soil (Anilkumar and Chakravarti 1970; Armon et al. 1995; Ficke et al. 1973; Rangarajan and Chakravarti 1970). In comparative studies with $P$. carotovorum, using non-sterile and heat-sterilized sand and mixtures of soil and sand, populations declined below the detection limit in one month in all non-sterile soils (Armon et al. 1995). In heat-sterilized soils, however, populations initially increased in size and could be detected 60 days after the last sampling date. Similarly, survival studies in which microcosms with a loam soil were used showed that in non-sterile soil in 50 days, a 10,000 -fold decrease $\left(10 \mathrm{E}^{8}-10 \mathrm{E}^{4} \mathrm{cells} / \mathrm{ml}\right)$ in the population density was found, while in gamma-radiated soils there was only a 100-fold decrease (Orvos et al. 1990). Lytic bacteriophages against SRP can be isolated relatively easily from soils in which infected plants are grown (Adriaenssens et al. 2012; Czajkowski et al. 2014; Lim et al. 2013). Survival of SRP may be influenced by parasitic organisms such as Bdellovibrio (Jurkevitch et al. 2000) and Myxococcus (Li et al. 2018b), which are soil bacteria that are often present in relatively high abundance. Numerous bacteria isolated from soil can compete with SRP through production of antimicrobial compounds, siderophores or interference via quorum quenching (Cirou et al. 2012; Czajkowski et al. 2012b; Jafra et al. 2009; Krzyzanowska et al. 2012). It is also possible that antagonistic fungi affect the survival of SRP in soil (Miles et al. 2012). 
Various abiotic factors have been found to influence the survival of SRP in soil, including temperature, moisture level and $\mathrm{pH}$ (Anilkumar and Chakravarti 1970; Ficke et al. 1973; Gudmestad and Secor 1983; Pérombelon and Hyman 1989). Studies on survival of $P$. atrosepticum in a loam soil indicated that the pathogen survived for a period of two months at a temperature of $2-10{ }^{\circ} \mathrm{C}$ compared to only 0.5 month at $20^{\circ} \mathrm{C}$. However, even in a sterile soil at $2-10^{\circ} \mathrm{C}$, the pathogen could not be detected after 4 months (Ficke et al. 1973). In these experiments, amending soil with organic material extended the survival periods: with alfalfa up to 260 days and with straw to a period even longer than 260 days (Ficke et al. 1973). P. atrosepticum survived for six months in various soils outside in Germany during wintertime. Survival of Dickeya sp. that can cause stalk-rot in maize was also favoured by a low temperature in soil, with the pathogen surviving in a loamy sand for 38 days at $8{ }^{\circ} \mathrm{C}$, for 22 days at $20{ }^{\circ} \mathrm{C}$ and for 12 days at $30{ }^{\circ} \mathrm{C}$ (Anilkumar and Chakravarti 1970). Survival was negatively influenced if the $\mathrm{pH}$ of the soil was adjusted from 8.3 to 4.8 , i.e. from 26 to 12 days (Anilkumar and Chakravarti 1970). Slightly longer survival periods (32 days) were found at low soil moisture levels (30\%) than at those exceeding $60 \%$ (22 days) (Anilkumar and Chakravarti 1970). Similarly, in Scotland longevity of $P$. carotovorum was greater in dry (10\% moisture) than in wet (21\% moisture) soils (Pérombelon and Hyman 1989). In other studies with a plant-free loam soil, a stalk rot causing agent described as $P$. carotovorum, survived for three months at $22{ }^{\circ} \mathrm{C}$ (Rangarajan and Chakravarti 1970). In comparison, in infected corn stalks, the pathogen could survive up to 22 months at $0-5{ }^{\circ} \mathrm{C}$ but only for $7-8$ months at 20-37 ${ }^{\circ} \mathrm{C}$. Addition of sodium nitrate $\left(70 \mathrm{mg} \mathrm{l}^{-1}\right)$ into non-sterile soil extended the survival period of $P$. carotovorum from 35 to 60 days (Armon et al. 1995). The authors concluded that irrigation with nitrate rich water may result in prolonged survival periods for $P$. carotovorum in soil. Survival of $P$. carotovorum was dependent on the soil depth; at a depth of $50 \mathrm{~cm}$ the period was shorter than at 30 or $10 \mathrm{~cm}$. Seemingly in contrast, in North Dakota $P$. carotovorum and $P$. atrosepticum were most frequently isolated in the $31-71 \mathrm{~cm}$ soil depth, suggesting that at this depth the bacteria were more protected from fluctuating moisture and temperature conditions (Gudmestad and Secor 1983). For potting media in glasshouses, a maximum survival period of 12 months for Dickeya spp. was reported (Haygood et al. 1982). The absence of strong fluctuating environmental conditions in greenhouses in comparison to field conditions may account for this long survival period.

Infected plant tissues, including roots, tubers and bulbs, can provide a source of bacteria to the soil, which may then be transmitted via free soil water, such as through irrigation or rainfall, to pathogen-free neighbouring plants. Water logging will also favour infection of tubers as a result of an impaired resistance against the pathogen (Smid et al. 1993). Field studies in the Netherlands were conducted in which an infected tuber was planted between pathogen-free mini-tubers. At the end of the growing season, the pathogen was found on up to the third plant in the same row and in a neighbouring plant of an adjacent row (Velvis and Van der Wolf 2009).

The risks of pathogen transmission from soil into a crop free of SRP are largely unknown. In the Netherlands, infected crop residues buried in soil in the autumn showed some transmission to Dickeya-free mini-tubers in the next growing season, 
but other infection sources could not be excluded (Velvis and Van der Wolf 2008). For bulbous ornamental crops there are also no indications that soil-borne inoculum plays a role in the epidemiology of the pathogen (van Doorn et al. 2011). Experiments in the Netherlands, in which crops inoculated with Dickeya spp. (hyacinth, iris, dahlia and muscari) or Pectobacterium spp. (zantedeschia) were grown in a field with a sandy soil, did not result in the following year in an increase of symptomatic plants from a non-inoculated crop grown in the same rotation (Van Doorn et al. 2011).

In conclusion, it appears unlikely that SRP persist for a period longer than one year in soil, at least in the absence of plant material (Anilkumar and Chakravarti 1970; Rangarajan and Chakravarti 1970; Lim 1975; Pérombelon and Hyman 1988). However, it cannot be ruled out that, under certain circumstances (e.g. temperature, water availability, plants present), levels of bacteria undetectable by current detection methodology may increase in number to colonize and even cause disease in suitable plant hosts.

\subsubsection{Soft Rot Pectobacteriaceae and the Role of Insects and Other Invertebrates}

Since the 1920s, it has been hypothesized that insects contribute to transmission of SRP. In an early example, it was observed that Delia platura (seedcorn maggot) laid eggs near seed tuber pieces shortly after planting and it was suspected that the larvae transmitted SRP to the tubers by boring into them (Leech 1926). Similarly, Delia radicum (cabbage root fly) and Delia antiqua (onion fly) were suggested to be closely associated with SRP and involved in the transmission of the bacteria to their respective host plants (Bonde 1930; Doane 1953; Doane and Chapman 1964). Later, it was shown that D. platura transmitted $P$. carotovorum from decayed tubers to wounded potato plants in a cage experiment (Phillips and Kelman 1982). The Delia genus belongs to the family Anthomyiidae ('root-maggot') and includes multiple species that are notorious plant pests on several crops. Delia species and SRP have a widely overlapping host-spectrum, giving far-reaching implications to the notion of a mutual relationship between the two. Furthermore, it was show that Drosophila melanogaster could transmit SRP from infected to healthy potato plants, while artificial inoculation of $P$. carotovorum and $P$. atrosepticum into Drosophila melanogaster showed that the bacteria could be transmitted to injured plants in the field (Kloepper et al. 1981; Molina et al. 1974). SRP were found to survive both internally and externally on Drosophila melanogaster and Drosophila buskii with some strains surviving in Drosophila spp. for at least 72 h ( Brewer et al. 1980, 1981).

In a Colorado field study, 10 genera from 9 families of dipterous insects ("true flies') collected in the field in the San Luis Valley of Colorado were contaminated with SRP (Kloepper et al. 1979). Recent research showed that SRP were ubiquitously present in or on insects, mainly Diptera, trapped in various potato fields spanning six latitudes and different climate zones throughout Norway (Rossmann et al. 2018). 
The insects that harboured SRP belonged to more than 90 different insect species, among which Delia species were most frequently found to be carriers. In addition to Delia platura, Delia coarctata ('wheat bulb fly'), Delia florilega ('bean seed maggot') and Delia radicum were among the insects most often associated with SRP. The widespread presence of SRP in various fly species is further supported by their detection in microbiome studies of house- and blowflies, as well as cactophilic (organisms adapted to survive in arid habitats) Drosophila species (Martinson et al. 2017; Junqueira et al. 2017). 16S barcoding has highlighted the abundance of OTU (operational taxonomy unit) related to Pectobacterium in the gut of Hyalesthes obsoletus (Hemiptera: Cixiidae), which is an important vector of phytoplasma diseases in grapevine (Iasur-Kruh et al. 2017), and in the gut of oriental fruit fly Bactrocera dorsalis (Wang et al. 2011). In addition, in several triatomine bugs, which are vectors of the protozoan parasite Trypanosoma cruzi, the causal agent of Chagas disease, Pectobacterium related OTU is also dominant (Díaz et al. 2016). The gut of the terrestrial slug Arion ater also hosted bacteria related to Pectobacterium (Joynson et al. 2014).

A general function of SRP in herbivorous insect species might explain their presence in so many insect species. SRP are notorious producers of a variety of plant cell wall-degrading enzymes (PCWDE) that are secreted to the extracellular environment, which could play a role in various insect-plant interactions. For example, the bacteria are thought to be generally beneficial to larval development of various Delia species by inducing rots. This perhaps helps the larvae to burrow into plant seeds, stems or roots where they feed until pupation or for the movement of the maize borer larvae - (Chilo partellus) through wound sites in growing maize crops (Dalmacio et al. 2007; Rossmann et al. 2018). They may also be involved in digestion in insects, e.g. pectinase producing bacteria in the guts of longhorn beetles or in helping to break down toxic plant components (Ivanova et al. 2006; Park et al. 2007). Many SRP species also possess genes related to nitrogen fixation (Bell et al. 2004; Toth et al. 2006), which has been demonstrated in vitro in several, but not all, strains of P. atrosepticum, P. carotovorum and D. dadantii (Toth I.K. and Brurberg M.B., unpublished results). Nitrogen fixation activity could in principle benefit hosts that feed on nitrogen deficient diets. Furthermore, SRP in the gut of D. radicum were shown to possess the ability to degrade a toxin produced by its host plants (Welte et al. 2015, 2016).

To date, no general molecular mechanisms governing an association between SRP and insects have been identified. However, for two SRP species, D. dadantii and $P$. carotovorum, specific molecular interactions with their respective insect hosts have been investigated in-depth. A cluster of four genes ( $c y t A, c y t B, c y t C$ and $c y t D)$ encoding proteins homologous to Bacillus thuringensis Cyt toxins was identified in the genome of $D$. dadantii 3937 (Grenier et al. 2006). In B. thuringensis, these toxins are produced together with the Cry toxins in parasporal crystals during sporulation and they have a cytolytic activity on insect cells. Very few bacteria outside $B$. thuringensis produce these toxins and cyt genes are not present in Pectobacterium spp. In laboratory experiments, $D$. dadantii was able to multiply and kill the pea aphid Acyrtosiphon pisum after 4-5 days following ingestion of an inoculum as low as 100 
bacteria. At the time of death, the insect contained up to $10^{7}$ bacteria (Costechareyre et al. 2012). A strain deleted in the four $c y t$ genes had a reduced virulence on aphids but no difference on plant aggressiveness was observed. Purified proteins from these genes were also found to kill aphids and may thus be a weapon against insects. Despite the presence of cyt genes, D. dadantii 3937 is not able to kill all insects. The bee Apis mellifera, the Lepidoptera Spodoptora littoralis and the fly Drosophila melanogaster were not affected by $D$. dadantii ingestion. The presence of $c y t$ genes in most Dickeya spp. suggests an ecological importance of these toxins, probably to kill some insects. Which insects are killed by Dickeya spp. and why is unknown. The cluster of four cyt genes is found in most Dickeya genomes, including the deep branching $D$. paradisiaca, indicating that it was present in the ancestor of Dickeya. However, it appears to be absent in D. fangzhongdai and in some D. zeae strains (Guy Condemine, INSA, Lyon, France, pers. comm.), although the ability of these strains to develop in or to kill aphids has not been tested. A study of the expression of $D$. dadantii cyt genes showed that they are regulated by the same regulators that control plant virulence factors. However, this regulation occurs in an opposite way, e.g. activators of plant virulence are repressors of Cyt production, suggesting that virulence against insects is integrated into the global bacterial virulence regulatory network (Costechareyre et al. 2010). To identify other genes involved in insect killing, a transcriptomic study of $D$. dadantii in A. pisum was performed. Although many genes in $D$. dadantii were induced whilst inside the insect, no other toxin or virulence genes were identified (Costechareyre et al. 2013).

Interactions between Pectobacterium spp. and insects have been less well studied. In a study to identify bacteria able to induce an immune response in $D$. melanogaster, Basset et al. (2000) identified the P. carotovorum 15 (Ecc15) strain, which is able to survive in the gut of the insect. A single gene, evf, is responsible for the colonization of the gut and overproduction of Evf allows a colonization of the body cavity, although its function is not known. The evf gene is not present in all Pectobacterium strains, and there are currently eight $P$. carotovorum strains and three $P$. versatile strains that encode proteins with identical sequences to the Ecc15 Evf, all deposited in GenBank (Basset et al. 2003).

While insect transmission of SRP to potato tubers and plants has been shown, it is unclear how frequently this occurs in agricultural settings, and which other crop plants may be affected. The recent findings of an association of various Pectobacterium spp. and $D$. solani with a wide variety of insect species, suggests that transmission of SRP by insects may be more common than previously assumed, which is especially relevant in the initial infection of clean seed material such as potato mini-tubers (Rossmann et al. 2018). However, it is not yet fully understood whether SRP are a mutualistic part of the microbiome of certain insect species, randomly acquired passengers or even pathogenic to insects that carry them.

In addition to insects, SRP have recently been found in other plant-associated animals, i.e. nematodes and gastropods. Grazing experiments performed with the model nematode Caenorhabditis elegans showed that $P$. atrosepticum is able to persist inside the nematode during digestion and can be released into the environment (Nykyri et al. 2014). Similarly, Chantanao and Jensen (1969) showed that $P$. 
carotovorum can survive passage through the nematode Pristionchus lheritieri and be defecated (Chantanao and Jensen 1969). When C. elegans was fed with P. carotovorum, $P$. atrosepticum or $P$. wasabiae, surface sterilized and placed onto potato tuber slices, soft rot symptoms could be detected after 2 days showing that nematodes may be a vector for these bacteria. The same result was obtained with the nematode Pristionchus sp. FIN-1, isolated from a tuber showing soft-rot symptoms (Nykyri et al. 2014). Thus, nematodes that are present in large numbers in the soil or decaying material could be vectors for SRP over short distances (or further in surface water and on machinery). D. dadantii and P. carotovorum have also been found in the intestinal microbiome of the black slug Arion ater (Joynson et al. 2017). These animals, which feed on a variety of plants, alive or decaying, can travel long distances and survive winter freezing conditions. If SRP are stable members of their microbiome, slugs could also be responsible for spread of SRP (Joynson et al. 2017).

\subsection{Colonisation, Infection and Symptoms of Plant Hosts}

\subsubsection{Colonisation and Infection}

SRP are present in multiple environments including soil, water, air, insects and nematodes (see Sect. 3.3). The pathogens can be present on the surface of field and processing machinery, stores and storage boxes and graders etc. (Elphinstone and Pérombelon 1986; Fehres and Linkies 2018; Kang et al. 2019). van Doorn et al. (2008) showed survival rates of different SRP on hard surfaces (including steel, concrete and PVC) and under different relative humidity (RH), e.g. survival only occurred on concrete at $95 \%$ humidity for any of these bacteria, for $6 \mathrm{~h}$ on PVC at $45 \% \mathrm{RH}$ but $48 \mathrm{~h}$ at $95 \% \mathrm{RH}$, while on PVC in the presence of plant resin bacteria survived for up to 100 days. SRP may also occur in artificial media used to grow plants, e.g. a major problem for cut flowers (Jowkar et al. 2013). There are therefore multiple sources from which plants can become contaminated. SRP often colonise the surface of different plants both with and without subsequent disease development and it is likely, therefore, that this colonisation is a natural part of SRP life cycle. For example, Buonaurio et al. (2015), identified Pectobacterium spp. as one of many natural colonisers of the aerial parts of olive trees and discussed the possibility that one or more of these bacterial species may assist the pathogen Pseudomonas savastanoi in the development of olive knot disease. Mutai et al. (2016), on the other hand, isolated Pectobacterium spp. as part of a natural diverse bacterial population from the roots of Brachiaria grass but not from the leaves, where other non-Pectobacterium spp. populations were present. There are also several examples of SRP being present on the roots of weed species within potato fields (see Sect. 3.2.4). It is therefore no surprise that roots, tubers and bulbs of crops and ornamental plants can become contaminated in a similar way. 
In potato, the main source of tuber contamination begins in lenticels and the stolon end. Under wet conditions, a layer of moisture forms around tubers leading to anaerobiosis, which causes opening of the lenticels, swelling of the cortical cells and increased cell membrane permeability, resulting in leakage and increased nutrient availability (Pérombelon 2002). Chemotaxis and motility then play a role in guiding SRP to these sites (Antunes-Lamas et al. 2009). Upon entry, the bacteria can remain in a latent state until conditions are conducive to bacterial multiplication. The exact conditions of latency are unclear but involve low numbers of bacteria prior to bacterial multiplication and may involve an equilibrium between protection and repair mechanisms in the pathogen, e.g. peptide methionine sulphoxide reductase (MsrA), and reactive oxygen levels in the plant (El-Hassouni et al. 1999; Pérombelon 2002). Anaerobiosis also reduces the effectiveness of oxygen-dependent plant defence mechanisms while allowing SRP to grow microaerophilically (Burton and Wigginton 1970). Free water, optimal temperature for bacterial growth, which differs between species, and reduced plant defences thus leads to bacterial growth.

Contamination (including a more permanent latent infection) of tubers is widespread in most commercial potato stocks and, where they are used for seed, early growth of the bacteria can prevent the plant from initiating (blanking), while later growth leads to cells moving into the growing plant stems (Pérombelon 1992). Once bacteria move from the mother tuber into the plant stem, they can colonise the cortex, multiply and are rapidly transported through the apoplastic spaces to the vascular system, where they first colonise parenchyma and then xylem tissues (Pérombelon et al. 1989). To achieve this, SRP produce a wide range of pathogenicity determinants, including PCWDE, and must also protect themselves from a variety of plant defence mechanisms (see Chap. 4).

As the bacteria spread through the vascular tissues, they can also move down the stolon into the developing progeny tubers, contaminating the stolon end of the tuber and adding to any new lenticellular contamination already present. Movement of the bacterial cells from here can in some infections by Dickeya spp. lead to a browning of the tuber vascular tissue (Toth et al. 2011). The fact that lenticels and the stolon end can both become contaminated by the bacteria, has led to both tissues being tested as part of diagnostics to measure the presence and level of SRP. While it is acknowledged that disease development is mainly initiated from contaminated mother tubers under disease-inducing conditions the bacteria, following contamination of the progeny tubers, can multiply within the tuber and cause local rots, including lenticellular/pit or stolon-end rot, which under extreme conditions can lead to severe damage or loss of the progeny tubers (see Sect. 3.5).

While mother tubers are the major route to invasion of potato plants and subsequent disease development, bacteria can also enter via the roots and canopy. Following inoculation of $D$. solani onto undamaged potato roots, bacteria were found inside the roots, stems and stolons 15 days after inoculation, with numbers increasing when damaged roots were used. Bacterial populations were found to be 2-3 times higher in the roots than the other structures (Czajkowski et al. 2010a). In roots, the bacteria were found associated with the parenchyma cells of the cortex and in the xylem and protoxylem of the stem. After 30 days following stem inoculation, D. solani 
was detected in the stems but also in the stem base, roots and to a lesser extent in the stolons and the stolon end of progeny tubers. Following leaf inoculation, at 42 dpi D. solani was detected in leaves, stems, stolons and occasionally in tubers, whereas $P$. parmentieri was restricted to leaves, stems and stolons, and could not be detected in tubers. The infection percentage was higher for plants with wounded leaves than for plants with untouched leaves, and higher at greater inoculum densities. Nevertheless, infection of leaves could also occur at low densities of D. solani $\left(10^{2}\right.$ cfu $\mathrm{mL}^{-1}$ ). Microscopic analysis indicated that both pathogens were able to penetrate and colonize hydathodes, stomata and wounds of inoculated leaves (Czajkowski et al. 2010b; Czajkowski et al. 2012). Similarly, Kubheka et al. (2013) observed that wounded and unwounded potato roots can become infected by $P$. brasiliense directly from the soil. However, wilting was more associated with seed borne than with soilborne inoculum (Ansernet et al. 2016). Chemotaxis, in addition to searching out nutrients, may also be involved in identifying sites of entry, and was found to have a more pronounced effect at colonising and entering some structures than others. For example, chemotaxis and motility mutants of $D$. dadantii were impaired in their ability to penetrate leaves of arabidopsis to a greater extent than their capacity to penetrate potato tubers, suggesting that chemotaxis and motility may be required as a more active entry mechanism for leaves than for tubers (Antunes-Lamas et al. 2008).

Once inside the xylem tissues, under conditions of low nutrient availability, $P$. atrosepticum and possibly other SRP produce extracellular polysaccharide (EPS), which surround the cells in a fibrous coat and, together with other bacterial structures (e.g. adhesins) and the bacterial-induced release of pectic polysaccharides (e.g. rhamnogalacturonan I) from the plant cell walls, leads to bacterial cell attachment and aggregation (Gorshkov et al. 2014, 2016; Rojas et al. 2002). Such biofilm structures support SRP to withstand water flow within the xylem and protect against plant defence mechanisms and is thought to be necessary for successful colonisation in xylem colonising bacteria (Leigh and Coplin 1992). In addition to biofilms, EPS-based multi-cellular structures called bacterial 'emboli' may be present, which appear not to be attached to the vessel walls (Gorshkov et al. 2014). Where bacterial cells aggregate in the xylem, in some cases the xylem becomes occluded leading to reducing water flow, wilting and eventually disease symptoms. However, where SRP are present in the xylem but the vessels are not occluded and no symptoms are apparent, transpiration is unaffected (Ansermet et al. 2016). At some point while in the xylem, probably following the production of EPS and formation of these multicellular structures, the bacteria begin to multiply and reach cell densities sufficiently high to trigger quorum sensing, a cell density-dependent regulatory process that triggers major changes in gene regulation (up to $26 \%$ of the genome) and with it the production of multiple, coordinated, pathogenicity determinants (Liu et al 2008; see Chap. 4). From this point, further bacterial multiplication, movement and occlusion of the xylem takes place followed by wilting and rotting. Intriguingly, Kubheka et al. (2013) showed that biofilm structures were more likely to be observed in susceptible 
potato cultivars, while in more tolerant cultivars bacterial cells remained in a freeswimming planktonic state, suggesting that mechanisms that limit biofilm formation may be the basis of tolerance in at least some cultivars.

While there is much less information on contamination (including source) and infection in plants other than potato, infections appear to follow a similar pattern. In a study in the Netherlands, Dickeya spp. were isolated from hyacinth and daffodil and $P$. carotovorum from Zantedeschia, with plants showing common symptoms of wilting, soft rot and decline (van Doorn et al. 2008). Disease incidence in several flower crops was found to be from bacteria present on the planted crop rather than transmitted from the soil (with few exceptions), in a similar way to contamination of seed potatoes. However, in Dieffenbachia, it was shown that a Dickeya sp. was able to infect via the roots initially to the xylem and then around the whole plant (Neivesbrun 1985). In Kalanchoe, Dickeya spp. were found in different parts of the plant including the stem base and upper parts (Bech 1994). Impaired host resistance due to water logging, optimal temperature, and wounding all increased infection and disease incidence caused by P. carotovorum in Zantedeschia (Wright et al. 2011).

Infection of maize by Dickeya spp. causes rots throughout the plant and occurs in the rainy season in the Philippines and elsewhere. The bacterium survives on crop residues and spreads to growing maize crops via water splash and insects (including the maize borer larvae-Chilo partellus) including through wound sites (Dalmacio et al. 2007; Thind and Singh 1975). In date palm trees, leaves turn yellow and vascular tissues (including those in the roots) discolour, suggesting that movement and establishment of the causal agent, Dickeya spp., occurs in the vessels, blocks transpiration and leads to rotting throughout the plant (Abdalla 2001). For sweet potato, bacteria can be present as latent infections (Duarte and Clark 1992), with oxygen deprivation and thresholds for both soil and air temperatures contributing to disease development (Edmunds et al. 2015).

\subsubsection{Disease Symptoms}

Diseases of potato tubers and plants caused by SRP induce a range of symptoms that can develop at every stage of the potato production cycle (Table 3.2). Soft rot symptoms can also be observed in ornamentals and in many vegetable crops.

\subsubsection{Soft Rot and Lenticel Rot of Potato Tubers}

Soft rot of potato tubers caused by SRP can occur in the field and in storage (Charkowski 2018). Early infection of seed tubers after planting can result in blanking (rotting or failure of the seed tuber to sprout) if the mother tuber rots or if young shoots are contaminated and killed before or just after emergence. During the growth of the potato plant, the bacteria can spread from the seed tuber to rot the stem and may also enter the progeny tubers via the stolons (Fig. 3.1A), where they can cause 
Table 3.2 Terminology of potato symptoms caused by SRP (from Pérombelon and Kelman 1987)

\begin{tabular}{l|l}
\hline Term & Explanation \\
\hline Non-emergence & Results from decay of seed tuber or early sprout death below ground \\
\hline Blackleg & $\begin{array}{l}\text { Infection originating from mother tuber and moving into the stem; } \\
\text { symptoms variable, ranging from black to dark brown basal stem rot to } \\
\text { wilting leaves/stems with or without yellowing. Infection is either limited } \\
\text { to the basal part of the plant or extended up to the top of the stem, } \\
\text { eventually associated with a hollowing of the stem }\end{array}$ \\
\hline Wilt & $\begin{array}{l}\text { Stem and leaf wilting often caused under warm conditions but with no } \\
\text { water deficit (stress) and with no stem rotting expression }\end{array}$ \\
\hline Stolon end rot & $\begin{array}{l}\text { Tan, brown to black decay lesion of the stem not originating at the } \\
\text { attachment point to the seed tuber }\end{array}$ \\
\hline Tuber soft rot & $\begin{array}{l}\text { Affects mostly progeny tubers of plants expressing blackleg symptoms; } \\
\text { brown to black necrosis }\end{array}$ \\
\hline Lenticel rot or pit rot & $\begin{array}{l}\text { Cream to tan colour and soft, granular consistency with brown colour } \\
\text { often developing at margins of decayed tissue; foul odour often } \\
\text { associated to the decayed tissue }\end{array}$ \\
\hline $\begin{array}{l}\text { Sunken brown to black decayed spots at points where lenticels become } \\
\text { infected. Can be limited to hard and dry symptoms when decay is stopped } \\
\text { at early stages after lenticel infection }\end{array}$ \\
\hline
\end{tabular}
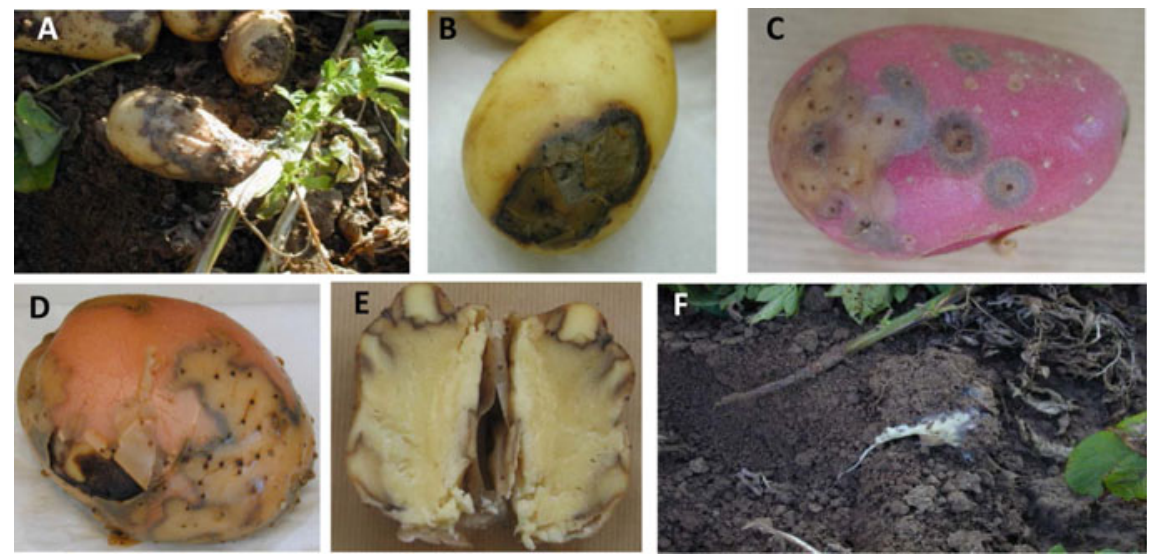

Fig. 3.1 Soft rot symptoms in potato tubers. (a) and (b) stolon end rot originating from the mother plant; (c) rotting of lenticels due to bacteria spreading into the tubers from soil; (d) and (e) advanced state of rotting of progeny tubers during field growth or in storage and (f) totally liquefied mother tuber in the field. Image credits: (a, b, d and f) Image credit Leah Tsror, Agricultural Research Organization, Gilat Center; (c and e) Valérie Hélias, French Federation of Seed Potato Growers, Rennes 
stolon end rot (Fig. 3.1B). During rainy weather, the bacteria can spread from infected plants into the soil, where they further spread with soil water (see Sect. 3.3) and infect tubers through lenticels, resulting in lenticel rot (Fig. 3.1C). In the later stages of tuber symptoms, a smelly rot develops and the whole tubers may rot (Fig. 3.1D), where the original site of infection is no longer obvious (Fig. 3.1E, F).

Rotting symptoms caused by different species of SRP are usually not distinguishable. However, at high temperatures $\left(>27^{\circ} \mathrm{C}\right)$, soft rot caused by D. solani can produce a creamy, cheesy rot developing to complete decay (Toth et al. 2011). It has been observed in Finland that the rot caused by $D$. solani can also occasionally appear pinkish in the early stages of the infection (Minna Pirhonen, personal information).

Rotting of the infected progeny tubers often only becomes visible at harvest or during storage, when rots may (further) develop under warm and humid conditions. Furthermore, the bacteria can spread from rotten plants and tubers through wounds caused at harvest, grading and packing. Sometimes, a localized sunken soft rot lesion, known as lenticel hard rot or pit rot, may develop on harvested tubers that have been covered with a film of water for some time and then become dry (Pérombelon and Kelman 1987).

\subsubsection{Potato Blackleg Symptoms}

The typical black rot of the stem base is called potato blackleg disease and is caused by the spread of bacteria from decaying mother tubers into the stem (Pérombelon and Kelman 1987). Blackleg symptoms can extend from one to several or all stems of the diseased potato plant. During the first stage of infection, the top leaves of affected stems turn light green to yellow and start to roll upward (Harrison and Nielsen 1986) (Fig. 3.2A). The entire stem then wilts, declines and dies. Symptoms occur at any stage of plant development but are much more likely during the summer months and towards the end of the growing season.

Blackleg symptoms can vary widely depending on prevailing environmental conditions. Usually, only the basal part of the stem turns black but in favourable conditions (high humidity) the decay may spread to the upper part of the stem (Fig. 3.2B) killing the whole plant (Fig. 3.2C). In wet conditions, blackleg symptoms are similar for Dickeya and Pectobacterium spp. (i.e. P. atrosepticum, P. brasiliense, P. parmentieri and P. punjabense) (Valérie Hélias, Leah Tsror, Minna Pirhonen, personal communication) regardless the temperature. Infected stems with the external darkening of typical blackleg (Fig. 3.2D) may or may not show symptoms of internal pith necrosis (Fig. 3.2E). The stem above the blackened part is often hollow and black.

Under dry warm conditions, infected tissues become dry and are often restricted to the underground portion of the stem but wilting, increased leaf desiccation, stem browning and hollowing of the stem may take place (Fig. 3.2F) (Tsror et al. 2009, Tsror et al. 2013). In contrast, under cool wet conditions, blackleg symptoms can develop without clear wilting (Czajkowski et al. 2011). 

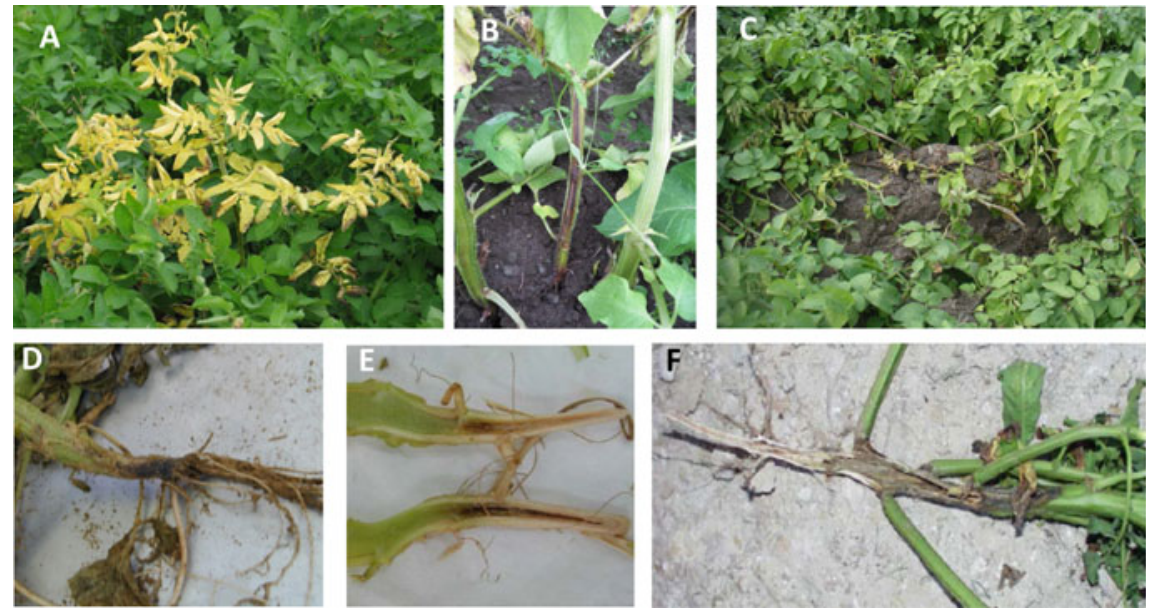

Fig. 3.2 Symptoms of potato blackleg. (a) yellowing is often the first symptom of blackleg followed by (b) rotting of the stems and (c) total collapse of the plants. (d) basal stem necrosis and (e) browning of the vascular tissue can be seen in the plants, together with (f) hollow stems, especially in warmer climates and in response to Dickeya spp. Image credits: (a) Asko Hannukkala, Natural Resources Institute LUKE, Jokioinen, Finland; (b and c) Minna Pirhonen, Department of Agricultural Sciences, University of Helsinki; (d and e) Leah Tsror, Agricultural Research Organization, Gilat Center; (f) Valérie Hélias, French Federation of Seed Potato Growers, Rennes

\subsubsection{Slow Wilting of Plants}

The typical symptom of $D$. solani in a hot climate $\left(>25^{\circ} \mathrm{C}\right)$ is slow wilt, which starts at the top leaves (Fig. 3.3A), spreads to the lower ones, and is then followed by desiccation of the entire plant, often without any visible blackleg symptoms (Fig. 3.3B, Fig. 3.4) (Tsror et al. 2009). Wilting is usually accompanied with a brown discoloration of the vascular system in the stem base (Fig. 3.3C).

In severe infections, the stem or whole plant dries out. This wilting and vascular browning resembles wilt caused by the fungal pathogen Verticillium dahliae (causal
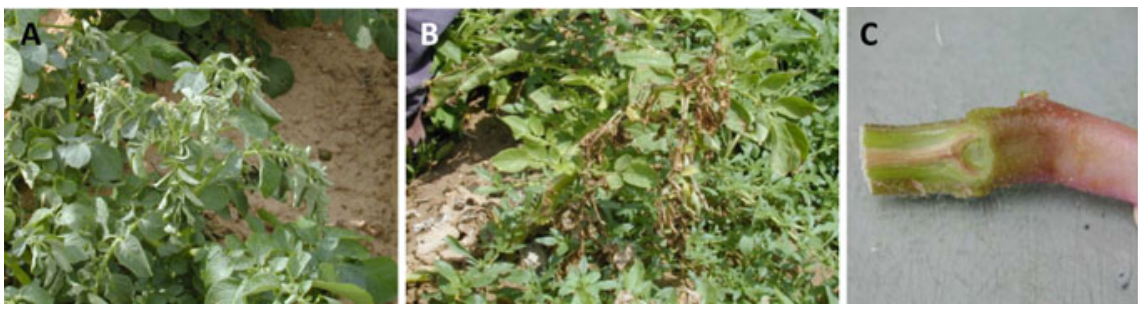

Fig. 3.3 Slow wilting of potato plants in warm climate. (a) Dickeya solani causes wilting of the potato plants that leads to leaf desiccation and (b) finally drying of the whole plants; (c) wilt is usually associated to discoloration of the stem base vascular system. Image credits: Leah Tsror, Agricultural Research Organization, Gilat Center 


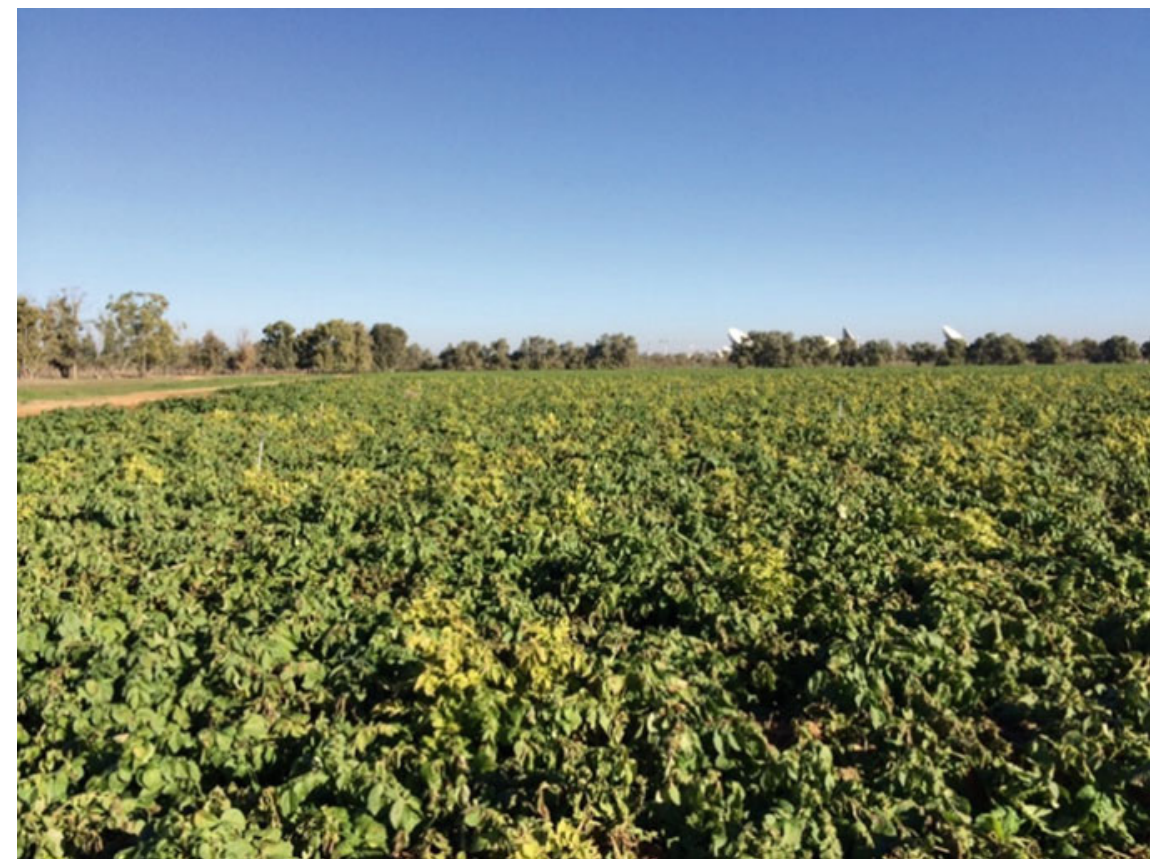

Fig. 3.4 Wilt and desiccation of the potato plants in the field. Image credit: Leah Tsror, Agricultural Research Organization, Gilat Center

agent of Verticillium wilt) and can occur immediately after irrigation under warm temperatures regardless the water status of the plant.

\subsubsection{Aerial Potato Stem Rot}

Aerial stem rot is a tan to brown decay lesion of the stem not originating at the attachment point of the seed tuber. It usually begins at breakage points in the stem, which then shows signs of rot at any level between the base and the top of the plant. In wet conditions, decay is a soft water-soaked rot that can expand along the stem and into the leaves and may spread to the entire plant (Fig. 3.5) (Harrison and Nielsen 1986). Stems, petioles, and leaves may become infected through wounds such as petiole scars, hail or wind damage or frequent overhead irrigation (Pérombelon and Kelman 1987). Lodged crops, with stems lying on the ground, often show aerial stem rot. This happens usually towards the end of the vegetative period when stems/crops are tall. 


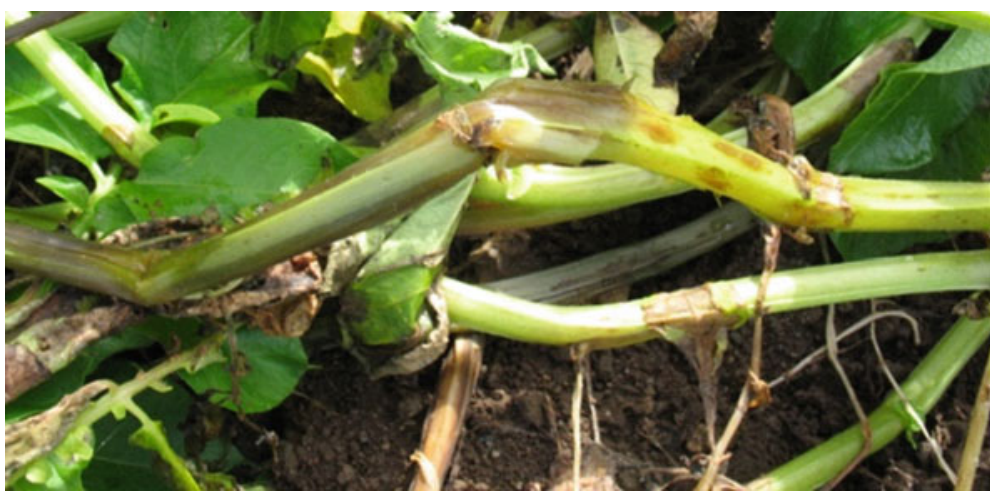

Fig. 3.5 Aerial stem rot of potato seen as watery rotten stems in the upper parts of the potato plant not originating at attachment point to seed tuber. Image credit: Valérie Hélias, French Federation of Seed Potato Growers, Rennes

\subsubsection{Symptoms of Soft Rot in Ornamental Plants}

Calla lily (Zantedeschia) (Araceae) is a genus of about eight species native to South Africa, all producing tuberous or rhizomatous storage organs that may be contaminated by P. carotovorum in the field or in storage (Snijder and van Tuyl 2002; Wright 1998). The first symptoms of soft rot disease in Calla lily plants are poor shoot growth and yellowing of the leaves (Luzzatto et al. 2007). Most often the leaves collapse, before the water soaked lesions appear. Under favorable warm and wet conditions the lesions enlarge rapidly, resulting in a soft decay of the whole plant. Usually the rot begins at the base of the leaf petioles (Fig. 3.6A) below or at the soil surface and may progress up the stems and down into the tubers (Snijder and van Tuyl 2002; Wright 1998). In some cases, the symptoms resemble black discoloration of healthy stems, accompanied by a rapid wilting, and yellowing of the leaves (Fig. 3.6B). Once the first disease symptoms occur under commercial greenhouse conditions, the dispersal may be rapid and losses may reach $50 \%$ of the yield (Fig. 3.6C).

Ornithogalum is a genus of ornamental flower bulbs belonging to the family Asparagaceae, that contains about 250-300 species, widely distributed in Asia and Africa (Littlejohn 2006). The African varieties of the plant are produced commercially as cut flowers and pot plants in South Africa, the USA, the Netherlands and Israel. The plant's potential as a cut flower or gardening plant is severely hampered by its susceptibility to bacterial soft rot caused by Pectobacterium spp. (Lipsky et al. 2014). Ornithogalum spp. are most suitable for the Mediterranean climate as they are easily forced to flower during the winter season. The first typical soft rot symptoms in Ornithogalum include small water-soaked lesions that appear on the leaf bases at the heart of the rosette (Fig. 3.7A). The typical lesions are apparently dependent on tiny water reservoirs at the leaf base, where bacteria may proliferate and intiate infection. Characteristic symptoms include small watery lesions that enlarge 

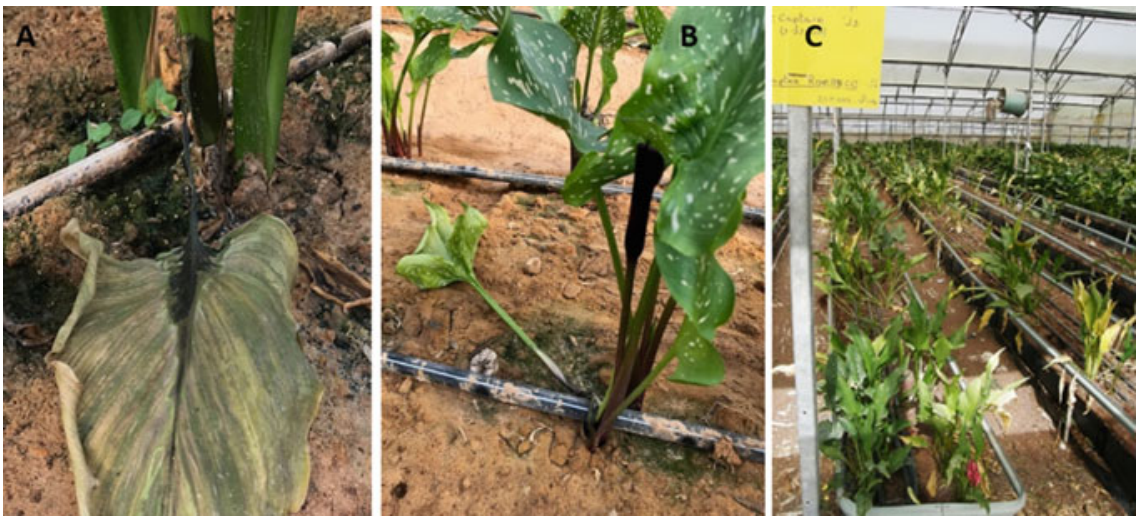

Fig. 3.6 Hybrid Zantedeschia plants displaying soft rot symptoms caused by Pectobacterium aroidearum infection, under greenhouse conditions at southern Israel. (a) blackening of the leaf petiole; (b) Zantedeschia hybrids planted in sandy soil, first soft rot symptoms occur when leaves are turning yellow and collapse; (c) Zantedeschia plants grown with drip irrigation on flower beds with soilless mixture of coil, peat moss and volcanic ash. Soft rot disease spreads throughout the flower beds with the irrigation lines. Image credits: Iris Yedidia, Agricultural Research Organization, Volcani Center
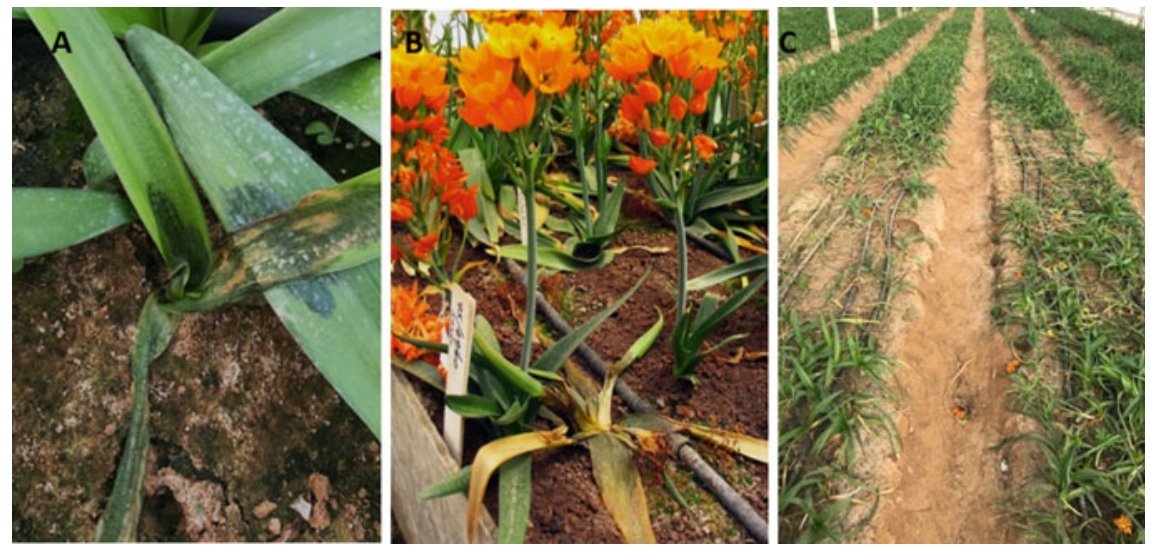

Fig. 3.7 Soft rot symptoms in Ornithogalum dubium plants, grown under greenhouse conditions during the winter season in Israel. (a) development of watery lesions at the heart of the leaves rosette and spread the neighboring plant; (b) severe soft rot decay and collapse of a mature flowering $O$. dubium plant; (c) Pectobacterium aroidearum spread at the greenhouse producing large rotten parches. Image credits: Iris Yedidia, Agricultural Research Organization, Volcani Center

rapidly to the entire plant and spread to the lower leaves and neighboring plants. Eventually, the stem and leaves are completely rotted (Fig. 3.7B) and the plant collapses, producing circles of decaying plant in the greenhouse (Fig. 3.7C). 
On Phalaenopsis orchid, infection begins as water-soaked spots on leaves pale to dark brown in colour. Some leaves have a yellow halo. As temperature and humidity increase, the spots enlarge to extend over the entire leaf blade exhibiting a light tan shade with darker brown boarder. Leaf tissues collapse and the infection spreads to the stem and pedicle, with the leaves eventually becoming dry (Zhou et al. 2012).

\subsubsection{Soft Rot Symptoms in Other Plants}

Pectobacterium and Dickeya spp. produce large quantities of cell wall degrading enzymes, which enable them to macerate and rot parenchymatous tissues of a wide range of plants (Fig. 3.8). The number of different crops associated with frequent and severe attacks, either before or after harvest, is significantly lower than the actual number of host species that become infected. The soft rot bacteria can infect plant material on their own or following attack by other pests and pathogens (Pérombelon and Salmond 1995). Soft rot can occur on a growing plant or on the harvested crop, in either storage or transit. Crops that are vegetatively reproduced (such as potato or carnation) can be systematically infected from the beginning of the production cycle. In most crops that are not reproduced in this way, soft rot lesions usually first occur on the aerial parts of the plant. Harvested crops, such as fleshy and leafy vegetables, exhibit similar symptoms (Pérombelon and Kelman 1980).

\subsection{Interactions Between SRP and Enteric Human Pathogens}

Enteric bacterial pathogens responsible for food borne diseases, such as nontyphoidal Salmonella spp. or pathogenic Escherichia coli, are traditionally associated with products of animal origin. However, outbreaks linked to the consumption of fresh fruits and vegetables presents a major public concern, with the number of cases of non-typhoidal Salmonella illness linked to fresh produce, spices and nuts surpassing those linked to foods of animal origin (Brandl et al. 2013). These human pathogens are not usually considered to cause disease on plants, but they can survive on leaves, penetrate plant tissues and maintain their population in the plant mesophyll. Furthermore, it is believed that Salmonella can sense the genotype or physiological state of its plant host and respond with distinct patterns of gene expression suggesting that plant colonization by Salmonella can be part of its life cycle (Brandl et al. 2013). This is hardly surprising since the genomes of the enteric human pathogens, particularly those associated with plants, share much in common with SRP (Toth et al. 2006).

The presence of phytopathogens, and particularly SRP, on fresh produce is a significant risk factor associated with increased Salmonella carriage on fruits and vegetables. This was first observed in supermarket fresh produce surveys, which demonstrated that $60 \%$ of fresh produce showing symptoms of soft rot also harboured 

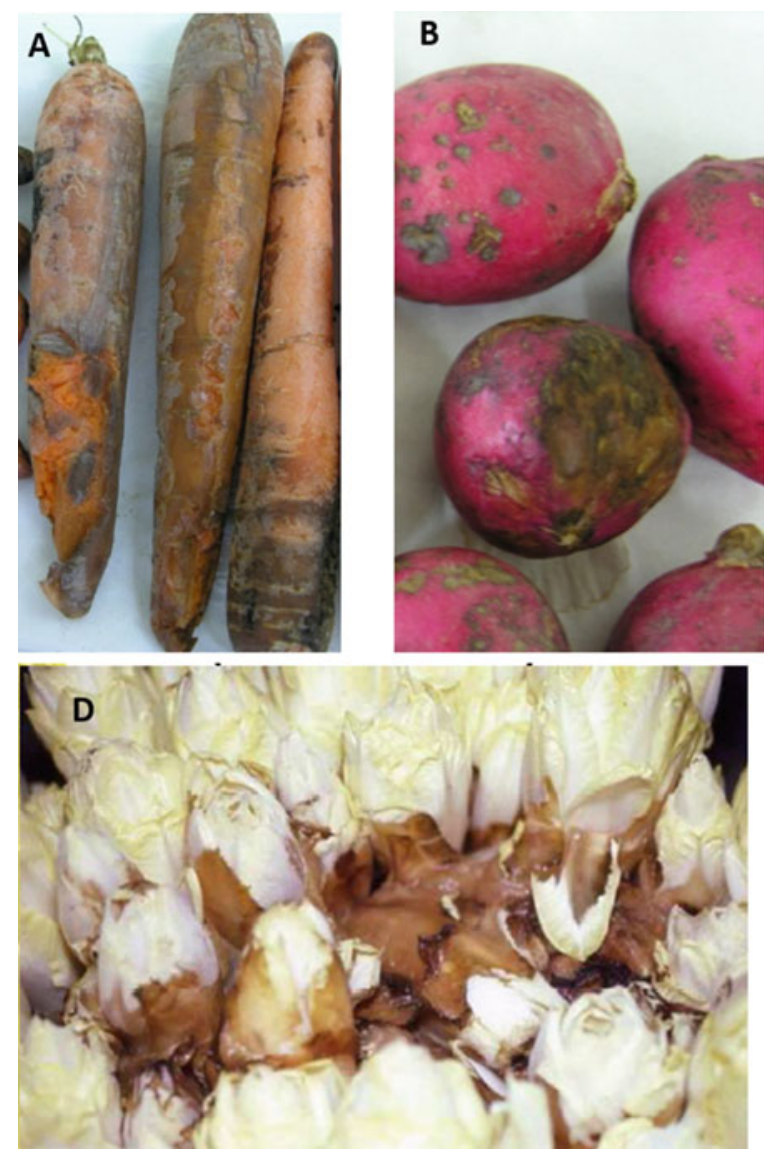
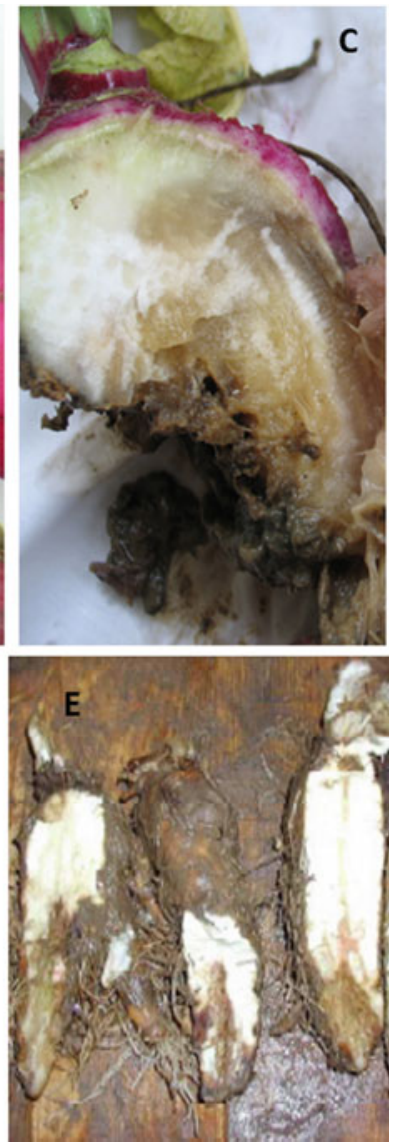

Fig. 3.8 Soft rot symptoms caused by Pectobacterium or Dickeya in vegetables such as (a) carrot, (b) radish including (c) radish seed crop, and (d) witloof leaves or (e) roots. Image credits: (a and b) Leah Tsror, Agricultural Research Organization, Gilat Center; (c-e) Valérie Hélias, French Federation of Seed Potato Growers, Rennes

presumptive Salmonella (Wells and Butterfield 1997). It was later documented by laboratory studies that maceration of plant tissues by $D$. dadantii or $P$. carotovorum promoted growth of Salmonella enterica and E. coli $\mathrm{O} 157: \mathrm{H} 7$, which reached population densities $10^{1}-10^{3}$ times greater on soft rot symptoms than on healthy plants (Brandl et al. 2013). This increase in human pathogen growth in the presence of soft rot symptoms was not observed after co-inoculation with SRP mutants impaired in the type II secretion system (Out), which prevents the secretion of SRP PCWDE out of the bacterial cell. This suggests that it may be plant tissue maceration rather than the presence of SRP that promotes enteric human pathogen growth (Yamazaki et al. 2011; George et al. 2018). This was further supported by studies on the $S$. enterica AHL receptor SdiA, which responds to the production of quorum sensing 
AHL signals by $P$. carotovorum in vitro but not in vivo. Analysis of SdiA mutants further demonstrated that detection of AHL produced by the soft rot bacterium $P$. carotovorum does not contribute to the fitness of $S$. enterica within tomato fruit (Noel et al. 2010). In a similar way, despite the fact that the Salmonella luxS gene was expressed during its invasion of a soft rot lesion, AI-2-based quorum sensing signalling in this pathogen did not appear to have an important role during its interactions with the plant pathogen P. carotovorum on tomato fruit (Cox et al. 2013). Thus, both sets of data appear to exclude the role of QS communication in Salmonella when present in planta together with SRP.

As maceration of plant tissues by SRP liberates a range of nutrients, metabolic interactions between Salmonella and SRP were investigated. Even though P. carotovorum lacks the enzymatic processes to utilise starch it is known to liberate amylose and amylopectin during the degradation of plant cells, while Salmonella spp. can digest starch. Salmonella starch utilization genes, such as amyA, are up-regulated in tomatoes macerated by $P$. carotovorum, although the corresponding Salmonella mutants exhibit the same fitness as the wild type parent in planta, indicating that starch utilization is not required for fitness within soft rot lesions (George et al. 2018).

Unlike phytopathogens, neither S. enterica nor $E$. coli can degrade pectin, although they can take up and metabolize pectin oligomers and monomers through a metabolic pathway identical to that of SRP (see Fig. 4.1). The genes involved in this pathway are up-regulated during growth on soft rotted plants. However, single or multiple mutations in genes of this pathway did not decrease the competitive fitness of the strains in planta, indicating that these genes are not required for Salmonella enhanced growth in macerated plant tissues (George et al. 2016). Transcriptomic profiling in lettuce and cilantro (Gaudeau et al. 2013) and transposon insertion sequencing, coupled with the phenotypic characterization of the mutants in healthy versus soft rotted tomatoes (George et al. 2018), both indicate that Salmonella spp. experience a metabolic shift in response to the changes in the environment brought on by $D$. dadantii or Pectobacterium spp. during plant tissue maceration. For example, Salmonella cells colonizing lettuce and cilantro leaf soft rot lesions caused by $D$. dadantii utilize a broad range of nutrients made available through the pectinolytic activity of the plant pathogen. These include fucose and rhamnose, two components of the plant cell wall that Salmonella can use as substrates to produce propanediol that, along with ethanolamine, can serve as carbon sources under anaerobic conditions (Gaudeau et al. 2013). This may explain the phenotype of Salmonella mutants deleted in the $k d g R$ gene, which encodes a negative regulator of the pectin degradation pathway (see Sect. 4.2.7). A significant increase in the fitness of the $k d g R$ mutant was observed in soft-rotted but not healthy tomatoes when compared to the fitness of the wild type parent (George et al. 2016). Even though the pectin degradation pathway is not involved in Salmonella enhanced fitness in soft rot tomatoes, metabolic profiling revealed that a $k d g R$ mutant was able to better utilize over 40 substrates, including rhamnose (George et al. 2016). 
Goudeau et al. (2013) demonstrated considerable overlap in genes up-regulated in cilantro and lettuce soft rot and in the animal intestine. Three-quarters of these upregulated genes are involved in metabolic processes, including propanediol production and metabolism, and propanediol utilization is required for Salmonella replication in macrophages and colonization of the chicken intestine (Goudeau et al. 2013). This indicates commonalities between conditions encountered by Salmonella in soft rot lesions and the host intestine and may give a clue to the adaptation of Salmonella spp. to macerated leaf tissue (Goudeau et al. 2013). Since SRP do not possess the propanediol catabolic pathway, Goudeau et al. (2013) proposed that, by macerating plant tissues, SRP provide to Salmonella spp. the necessary substrates for propanediol biosynthesis and catabolism, while using the oligogalacturonides released by lysis of the plant cell wall and thus create a nutritional environment with partitioned resources and an apparent lack of competition between both bacterial species. The situation is different in a micro-aerophilic environment, such as that encountered in modified atmosphere packaging (MAP) used to extend shelf life of produce by reducing the rate of plant respiration, ethylene production and growth of microorganisms responsible for spoilage. Under these conditions, $S$. enterica growth was still enhanced by the presence of $P$. carotovorum while $S$. enterica, but not E. coli O157:H7, reduced $P$. carotovorum growth rates, final population densities and soft rot progression (Kwan et al. 2013). This is partly due to $\mathrm{pH}$ manipulation of the rooted tissues by Salmonella spp. Indeed, under micro-aerophilic conditions, S. enterica acidifies the phyllosphere due to production of organic acids during fermentation. This acidification interferes with the ability of $P$. carotovorum to alkalinize plant tissues to reach the $\mathrm{pH}$ required for optimal activity of the pectate lyases responsible for plant tissue maceration (Kwan et al. 2013).

\subsection{Conclusions}

SRP cause diseases on a wide range of plants globally. Some have wide host ranges while others appear to infect a single plant species. In other cases, particularly newly named species, SRP have been found in the wider environment not associated with plants e.g. water systems. Future research may tell us whether these niches are their natural habitat or whether plant hosts (that develop disease or not) are out there yet to be discovered. While we know surprisingly little about SRP in the wider environment and their life away from the diseased host, we do know that for some plants, particularly crops and ornamentals, disease can be devastating. While this is particularly true for potato and other 'soft fleshed' vegetables, where disease losses can be huge, we must be thankful that other main staple crops such as maize and rice, which may also succumb to SRP diseases, do so to a much lesser extent. Even where SRP are present on a plant that does not normally succumb to disease, their proximity to crops and ornamentals, e.g. weeds in a field, offers the potential for spread and subsequent disease development. 
These pathogens appear to live in the environment as part of their natural existence and can be found in water, soil and in the atmosphere. However, these niches also provide a means to spread these bacteria leading to colonisation of plants, e.g. through irrigation, growth in soil and in aerosols, the latter two particularly under wet conditions. There is also evidence that insects and other invertebrates help to spread SRP although, surprisingly, the extent to which this occurs is unclear.

For many plants SRP do no more than colonise, and whether this has a neutral, negative or even positive effect is not known. However, in certain environmental conditions, mostly a suitable temperature and a wet environment with reduced oxygen availability, infection takes place leading, in some cases, to disease symptoms and losses. Whatever the plant being infected, the process and ultimate symptoms are strikingly similar across different plant types, which might also suggest common approaches to disease control.

Finally, disease and subsequent economic losses may not be the only thing arising from the presence of SRP on plants. There is growing evidence that they may also coexist with enteric human and animal pathogens, e.g. E. coli and Salmonella spp., to help promote the growth of, and share nutrients with, these closely related pathogens thus bringing a human and animal health aspect to their presence on plants.

\section{References}

Abdalla MY (2001) Sudden decline of date palm trees caused by Erwinia chrysanthemi. Plant Dis $85: 24-26$

Adriaenssens EM, Van Vaerenbergh J, Vandenheuvel D, Dunon V, Ceyssens PJ, De Proft M et al (2012) T4-related bacteriophage LIMEstone isolates for the control of soft rot on potato caused by 'Dickeya solani'. PLoS ONE 7:e33227

Ahmed Y, Mirza MS, Ghaffar A (2000) Pathogens associated with stalk rot of corn in Pakistan. Pak J Bot 32:251-253

Alič Š, Van Gijsegem F, Pédron J, Ravnikar M, Dreo T (2018) Diversity within the novel Dickeya fangzhongdai sp., isolated from infected orchids, water and pears. Plant Pathol 67:1612-1620

Alic S, Naglic T, Llop P, Toplak N, Koren S, Ravnikar M, Dreo T (2015) Draft genome sequence of Dickeya sp. Isolates B16 (NIB Z 2098) abd S1 (NIB Z 2099) causing soft rot of Phalaenopsis orchids. Microbiol Res Announcements 3:e00973-e1015

Anilkumar TB, Chakravarti BP (1970) Factors affecting survival of Erwinia carotovora causal organism of stalk rot in maize in soil. Acta Phytopathologica Academiae Scientiarum Hungaricae $5: 333-340$

Ansermet M, Schaerer S, Kellenberger I, Tallant M, Dupuis B (2016) Influence of seed-borne and soil-carried inocula of Dickeya spp. On potato plant transpiration and symptom expression. Eur J Plant Pathol 145:459-467

Armon R, Dosoretz C, Yoirish A, Shelef G, Neeman I (1995) Survival of the phytopathogen Erwinia carotovora subsp. carotovora in sterile and nonsterile soil, sand and their admixture. J Appl Bacteriol 79:513-518

Arun WA, Bohra P, Umesha K, Chandrashekar SC, Sathyanarayana BN, Sreeramu BS (2012) Successful rescue and field establishment of native banana varieties severely affected by rhizome rot. J Agric Rural Dev Trop Subtrop 113:147-154 
Askari S, Rezaei R, Sadravi M, Taghavi SM. Identification of Dickeya dadantii Samson, et al (2018) 2005 sp. Nov. (Erwinia chrysanthemi 3937) as a causal agent of bacterial stalk rot of maize in southwest of Iran. Trop Agric 95:146-153

Baghaee-Ravari S, Rahimian H, Shams-Bakhsh M, Lopez-Solanilla E, Antúnez-Lamas M, Rodríguez-Palenzuela P (2011) Characterization of Pectobacterium species from Iran using biochemical and molecular methods. Eur J Plant Pathol 129:413-425

Bain RA, Pérombelon MCM, Tsror L, Nachmais A (1990) Blackleg development and tuber yield in relation to numbers of Erwinia carotovora subsp. atroseptica on seed potatoes. Plant Pathol 39:125-133

Basim H, Basim E, Baki D, Turgut A (2019) Wet rot disease of banana (Musa sp.) caused by Pectobacterium carotovorum subsp. carotovorum in Turkey. Can J Plant Path 41:174-187

Basset A, Khush RS, Braun A, Gardan L, Boccard F, Hoffmann JA, Lemaitre B (2000) The phytopathogenic bacteria Erwinia carotovora infects Drosophila and activates an immune response. Proc Natl Acad Sci USA 97:3376-3381

Basset A, Tzou P, Lemaitre B, Boccard F (2003) A single gene that promotes interaction of a phytopathogenic bacterium with its insect vector, Drosophila melanogaster. EMBO Rep 4:205209

Bech K (1994) Spread of Erwinia chrysanthemi in Kalanchoe blossfeldiana. J Phytopathol 141:285292

Bell KS, Sebaihia M, Pritchard L, Holden MTG, Hyman LJ, Holeva LC, Thomson MR, Bentley SD, Churcher LJC, Mungall K et al (2004) Genome sequence of the enterobacterial phytopathogen Erwinia carotovora subsp. atroseptica and characterization of virulence factors. Proc Natl Acad Sci USA 101:11105-11110

Blomme G, Dita M, Jacobsen KS, Vincente LP, Molina A, Ocimati W, Poussier S, Prior P (2017) Bacterial diseases of banana and enset: current state of knowledge and integrated approaches towards sustainable management. Front Plant Sci 8:Article 1290

Boccara M, Vedel R, Lalo D, Lebrun MH, Lafey JF (1991) Genetic diversity and host range in strains of Erwinia chrysanthemi. Mol Plant-Microbe Interact:4I293-299

Bonde R (1930) The cabbage maggot as a disseminating agent of bacterial rots in the Cruciferae. Phytopathology 20:128

Brandl MT, Cox CE, Teplitski M (2013) Salmonella interactions with plants and their associated microbiota. Phytopathology 103:316-325

Brewer JW, Harrison MD, Winston JA (1980) Differential attraction of Drosophila melanogaster Meig. to potato tissue infected with two varieties of Erwinia carotovora. Am J Potato Res 57:219224

Brewer J, Harrison MD, Winston JA (1981) Survival of two varieties of Erwinia carotovora on Drosophila melanogaster meigen and Drosophila buskkii coquillett, (Diptera: drosophilidae) vectors of potato blackleg in Colorado. Am Potato J 58:439-449

Burr TJ, Schroth MN (1977) Occurrence of soft rot Erwinia spp. in soil and plant material. Phytopathology 67:1382-1387

Burton WG, Wigginton MJ (1970) The effect of a film of water upon the oxygen status of a potato tuber. Potato Res 13:150-186

Byther RS, Chastagner GA (1993) Diseases. In: De Hertogh A, Le Nard M (eds) The physiology of flower bulbs. Elsevier Science, Amsterdam, pp 71-100

Cabrera-Huerta E, Aranda-Ocampo S, Hernandez-Castro E, Nava-Diaz C (2019) First report of bacterial wilt caused by Dickeya chrysanthemi on Agave-Mezcal (Agave cupreata). in Mexico. Plant Dis 103:1406

Cahill G, Fraser K, Kowalewska M, Kenyon D, Saddler G (2010) Recent findings from the Dickeya survey and monitoring programme. In: Proceedings of the Dundee conference. Crop protection in Northern Britain, Dundee, UK, 23-24 February 2010, 2010: The Association for Crop Protection in Northern Britain, pp 171-176

Cappaert MR, Powelson ML (1987) Irrigation water as a source of inoculum of soft rot erwinias for Aerial Stem Rot of Potatoes. Phytopathology 77:1768-1768 
Cappaert MR, Powelson ML, Franc GD, Harrison MD (1988) Irrigation water as a source of inoculum of soft rot erwinias for aerial stem rot of potatoes. Phytopathology 78:1668-1672

Cating RA, Hong JC, Palmateer AJ, Stiles CM, Dickstein ER (2008) First report of bacterial soft rot on Vanda orchids caused by Dickeya chrysanthemi (Erwinia chrysanthemi) in the United States. Plant Dis 92:977

Cating RA, Hoy MA, Palmateer AJ (2010) A comparison of standard and high-fidelity PCR in the detection of Sclerotium rolfsii and a Dickeya sp. From Phalaenopsis orchids. Phytopathology 100:S22

Cating RA, Palmateer AJ, McMillan RT, Dickstein ER (2009) First report of a bacterial soft rot on Tolumnia orchids caused by a Dickeya sp in the United States. Plant Dis 93:1354-1354

Chantanao A, Jensen HJ (1969) Saprozoic nematodes as carriers and disseminators of plant pathogenic bacteria. J Nematol 1:216-218

Charkowski AO (2018) The changing face of bacterial soft-rot diseases. Annu Rev Phytopathol $56: 269-288$

Charkowski AO (2006) The soft rot Erwinia. Plant-Assoc Bacteria Part 3:423-505

Chattopadhyay PK, Murkherjuee N (1986) A Pseudostem rot of banana due to Erwinia chrysanthemi pv. paradisiaca. Curr Sci 55:789-790

Chio JE, Park JS, Kang HW (1988) Bacterial soft rot of banana fruit caused by Erwinia carotovora subsp. carotovora and Pseudomonas cichorii. Korean J Plant Pathol 3:202-206

Cirou A, Mondy S, An S, Charrier A, Sarrazin A, Thoison O et al (2012) Efficient biostimulation of native and introduced quorum quenching Rhodococcus erythropolis populations is revealed by a combination of analytical chemistry, microbiology, and pyrosequencing. Appl Environ Microbiol 78:481-492

Costechareyre D, Balmand S, Condemine G, Rahbé Y (2012) Dickeya dadantii, a plant pathogenic bacterium producing Cyt-like entomotoxins, causes septicemia in the pea aphid Acyrthosiphon pisum. PLoS ONE 7:e30702

Costechareyre D, Chich J-F, Strub J-M, Rahbé Y, Condemine G (2013) Transcriptome of Dickeya dadantii infecting Acyrthosiphon pisum reveals a strong defense against antimicrobial peptides. PLoS ONE 8:e54118

Costechareyre D, Dridi B, Rahbé Y, Condemine G (2010) Cyt toxin expression reveals an inverse regulation of insect and plant virulence factors of Dickeya dadantii. Environ Microbiol 12:3290 3301

Cother E, Bradley J, Gillings M, Fahy P (1992) Characterization of Erwinia chrysanthemi biovars in alpine water sources by biochemical properties, GLC fatty acid analysis and genomic DNA fingerprinting. J Appl Bacteriol 73:99-107

Cother E, Gilbert R (1990) Presence of Erwinia chrysanthemi in two major river systems and their alpine sources in Australia. J Appl Bacteriol 69:729-738

Cox CE, McClelland M, Teplitski M (2013) Consequences of disrupting Salmonella AI-2 signalling on interactions within soft rots. Phytopathology 103:352-361

Czajkowski R, de Boar WJ, Velvis H, van der Wolf JM (2010a) Systemic colonisation of potato plants by a soil-borne, green fluorescent protein-tagged strain of Dickeya sp biovar 3. Phytopathology 100:134-142

Czajkowski R, de Boer WJ, van der Zouwen PS, Kastelein P, Jafra S, de Haan EG, van den Bovenkamp GW, van der Wolf JM (2012) Virulence of 'Dickeya solani' and Dickeya dianthicola biovar-1 and -7 strains on potato (Solanum tuberosum). Plant Pathol 62:597-610

Czajkowski R, de Boer WJ, van Veen JA, van der Wolf JM (2010b) Downward vascular translocation of a green flurescent protein-tagged strain if Dickeya sp. (Biovar 3) from stem and leaf inoculation sites on potato. Phytopathology 100:1128-1137

Czajkowski R, Ozymko Z, Lojkowska E (2014) Isolation and characterization of novel soilborne lytic bacteriophages infecting Dickeya spp. biovar 3 ('D. solani'). Plant Pathol 63:758-772

Czajkowski R, Pérombelon MCM, van Veen JA, van der Wolf JM (2011) Control of blackleg and tuber soft rot of potato caused by Pectobacterium and Dickeya species: a review. Plant Pathol 60:999-1013 
Dalmacio SC, Ludog TR, Sarrano EM, Munkvold GP (2007) Reduced incidence of bacterial tot on transgenic insect resistant maize in the Philippines. Plant Dis 91:346-351

De Boer SH, Allan E, Kelman A (1979) Survival of Erwinia carotovora in Wisconsin soils. Am Potato J 56:243-252

Dees MW, Lysoe E, Rossmann S, Perminow J, Brurberg MB (2017) Pectobacterium polaris sp nov., isolated from potato (Solanum tuberosum). Int J Syst Environ Microbiol 67:5222-5229

Díaz S, Villavicencio B, Correia N, Costa J, Haag KL (2016) Triatomine bugs, their microbiota and Trypanosoma cruzi: asymmetric responses of bacteria to an infected blood meal. Parasites Vectors 9: Article 636.

Doane CC (1953) The onion maggot in Wisconsin and its relation to rot in onions. $\mathrm{PhD}$ thesis. University of Wisconsin-Madison

Doane JF, Chapman RK (1964) The relation of the cabbage maggot, Hylemya brassicae (Bouché), to decay in some cruciferous crops. Entomol Exp Appl 7:1-8

du Raan S, Coutinho TA, van der Waals JE (2016) Cardinal temperature differences, determined in vitro, between closely related species and subspecies of pectinolytic bacteria responsible for blackleg and soft rot on potatoes. Eur J Plant Pathol 144:361-369

Duarte V, Clark CA (1992) Presence on sweet potato through the growing season of Erwinia chrysanthemi, cause of stem and root rot. Plant Dis 76:67-71

Edmunds BA, Clark CA, Villordon AQ, Holmes GJ (2015) Relationships of preharvest weather conditions and soil factors to susceptibility of sweet potato to postharvest decay caused by Rhizopus stolonifera and Dickeya dadantii. Plant Dis 99:848-857

El Hassouni M, Chambost JP, Expert D, Van Gijsegem F, Barras F (1999) The minimal gene set member $m s r A$, encoding peptide methionine sulfoxide reductase, is a virulence determinant of the plant pathogen Erwinia chrysanthemi. Proc Natl Acad Sci USA 96:887-892

Elphinstone J, Pérombelon M (1987) Control of contamination of potatoes with airborne Erwinia carotovora by foliar application of copper oxychloride. Ann Appl Biol 110:535-544

Elphinstone JG, Pérombelon MCM (1986) Contamination of potatoes by Erwinia carotovora during grading. Plant Pathol 35:25-33

Faye P, Bertrand C, Pédron J, Barny M-A (2018) Draft genomes of "Pectobacterium peruviense" strains isolated from fresh water in France. Stand Genom Sci 13:27

Fehres H, Linkies A (2018) A mechanized two-step cleaning and disinfection process strongly minimizes pathogen contamination on wooden potato storage boxes. Crop Protect 103:111-114

Ficke W, Naumann K, Skadow K, Müller H, Zielke R (1973) Die Lebensdauer von Pectobacterium carotovorum var. atrosepticum (van Hall) Dowson auf dem Pflanzgut und im Bodem. Arch Phytopathol Plant Protect 9:281-293

Fikowicz-Krosko J, Wszalek-Rozek K, Smolarska A, Czajkowski R (2017) First report of isolation of soft rot Pectobacterium carotovorum subsp. carotovorum from symptomless bittersweet nightshade occurring in rural area of Poland. J Plant Pathol 99:294-294

Franc GD, Harrison MD (1987) The role of contaminated irrigation water in the recontamination of Erwinia-free seed potatoes. Am Potato J 64:438-438

Franc GD (1988) Long distance transport of Erwinia carotovora in the atmosphere and surface water. PhD, Colorado State University

Fujikawa T, Ota N, Sasaki M, Taiki N, Toru I (2019) Emergence of apple bacterial quick decline caused by Dickeya dadantii in Japan. J Gen Plant Pathol 85:314-319

Ge TL, Hao J, Johnson S (2017) Induced viable but non-culturable (VBNC) state in Dickeya dianthicola. Phytopathology 107:200

George AS, Cox CE, Desai P, Porwollik S, Chu W, de Moraes MH, McClelland M, Brandl MT, Teplitski M (2018) Interactions of Salmonella enterica serovar Typhimurium and Pectobacterium carotovorum within a tomato soft rot. Appl Environ Microbiol 84:e01913-e1917

George AS, Gonzalez IS, Lorca GL, Teplitski M (2016) Contribution of the Salmonella enterica $\mathrm{KdgR}$ regulon to persistence of the pathogen in vegetable soft rots. Appl Environ Microbiol $82: 1353-1360$ 
Gokul G, Louis V, Namitha PM, Mathew D, Girija D, Shilaja MR, Abida PS (2019) Variability of Pectobacterium carotovorum causing rhizome rot in banana. Biocatal Agric Biotechnol 17:60-81

Gorshkov V, Daminova A, Ageeva M, Petrova O, Gogoleva N, Tarasova N, Gogolev Y (2014) Dissociation of a population of Pectobacterium atrosepticum SCRI1043 in tobacco plants: Formation of bacteria emboli and dormant cells. Protoplasma 251:499-510

Gorshkov VY, Daminova AG, Mikshina PV, Petrova OE, Ageeva MV, Salnikov VV, Gorshkova TA, Gogolev YV (2016) Pathogen-induced conditioning of the primary xylem vessels - a prerequisite for the formation of bacterial emboli by Pectobacterium atrosepticum. Plant Biol 18:609-617

Gorshkov VY, Petrova OE, Mukhametshina NE, Ageeva MV, Mulyukin AL, Gogolev YV (2009) Formation of "Nonculturable" dormant forms of the phytopathogenic enterobacterium Erwinia carotovora. Microbiology 78:585

Goto M (1979) Bacterial foot rot of rice caused by a strain of Erwinia chrysanthemi. Phytopathology 69:213-216

Goudeau DM, Parker CT, Zhou Y, Sela S, Kroupitski Y, Brandl MT (2013) The Salmonella transcriptome in lettuce and cilantro soft rot reveals a niche overlap with the animal host intestine. Appl Environ Microbiol 79:250-262

Graham D, Quinn C, Sells IA, Harrison M (1979) Survival of strains of soft rot coliform bacteria on microthreads exposed in the laboratory and in the open air. J Appl Bacteriol 46:367-376

Grenier A-M, Duport G, Pagès S, Condemine G, Rahbé Y (2006) The phytopathogen Dickeya dadantii (Erwinia chrysanthemi 3937) is a pathogen of the pea aphid. Appl Environ Microbiol 72:1956-1965

Gudmestad NC, Secor GA (1983) The bionomics of Erwinia carotovora in North Dakota. Am Potato J 60:759-771

Harrison M, Franc G, Maddox D, Michaud J, Mccarter-Zorner N (1987) Presence of Erwinia carotovora in surface water in North America. J Appl Bacteriol 62:565-570

Harrison MD, Nielsen JM (1986) Compendium of potato diseases. In: Hooker WJ (ed) American Phytopathological Society, pp 27-28

Hassanzadeh N (1990) Characterization of a new soft rot Erwinia to banana in Iran. Iranian J Plant Pathol 26:13-18

Haygood RA, Strider DL, Echandi E (1982) Survival of Erwinia chrysanthemi in association with Philodendron selloum other greenhouse ornamentals and in potting media. Phytopathology 72:853-859

Hellmers E (1958) Four wilt diseases of perpetual flowering carnations in Denmark. Dansk Botanisk Arkiv 18:95-140

Hu, M,; Li J, Chen R, Li W, Feng L, Shi L, Xue Y, Feng X, Zhang L, Zhou J, et al (2018) Dickeya zeae strains isolated from rice, banana and clivia rot plants show great virulence differentials. BMC Microbiol 18:136

Huang YF, Liu CY, Wang H, Guan TS, Liu L (2017) Bacterial soft rot of eggplant caused by Pectobacterium carotovorum subsp. carotovorum in China. J Plant Pathol 99:810-810

Hugouvieux-Cotte-Pattat N, Brochier-Armanet C Flandrois J-P, Reverchon S (2020) Dickeya poaceiphila sp. nov., a plant-pathogenic bacterium isolated from sugar cane (Saccharum officinarum). Int J Syst Evol Microbiol (in press)

Hugouvieux Cotte Pattat N, Jacot des Combes C, Briolay J, (2019) Dickeya lacustris sp. nov., a water-living pectolytic bacterium isolated from lakes in France. Int J Syst Evol Microbiol 69:721-726

Iasur-Kruh L, Naor V, Zahavi T, Ballinger MJ, Sharon R, Robinson WE, Perlman SJ, Zchori-Fein E (2017) Bacterial associates of Hyalesthes obsoletus (Hemiptera: Cixiidae), the insect vector of bois noir disease, with a focus on cultivable bacteria. Res Microbiol 168:94-101

Ivanova NV, Dewaard JR, Hebert PDN (2006) An inexpensive, automation-friendly protocol for recovering high-quality DNA. Mol Ecol Notes 6:998-1002

Jaffar NS, Osman MS, Koyube MNK (2019) New bacterial fruit rot disease of jackfruit caused by Dickeya fangzhongdai in Malaysia Malaysian. J Microbiol 15:314-319 
Jafra S, Przysowa J, Gwizdek-Wisniewska A, van der Wolf JM (2009) Potential of bulb-associated bacteria for biocontrol of hyacinth soft rot caused by Dickeya zeae. J Appl Microbiol 106:268-277

Jorge P, Harrison M (1986) The association of Erwinia carotovora with surface water in northeastern Colorado. I. The presence and population of the bacterium in relation to location, season and water temperature. Am Potato J 63:517-531

Jowkar MM, Khalighi A, Kafi M, Hassanzadeh N (2013). Evaluation of aluminium sulfate as vase solution biocide on postharvest microbial and physiological properties of 'Cheery Brandy' rose. In: VII International Postharvest symposium, vol 1012, pp 615-626

Joynson R, Pritchard L, Osemwekha E, Ferry N (2017) Metagenomic analysis of the gut microbiome of the common black slug arion ater in search of novel lignocellulose degrading enzymes. Front Microbiol 8:2181

Joynson R, Swamy A, Bou PA, Chapuis A, Ferry N (2014) Characterization of cellulolytic activity in the gut of the terrestrial land slug Arion ater: Biochemical identification of targets for intensive study. Comp Biochem Physiol B-Biochem Mol Biol 177:29-35

Junqueira ACM, Ratan A, Acerbi E, Drautz-Moses DI, Premkrishnan BNV, Costea PI, Linz B, Purbojati RW, Paulo DF, Gaultier NE, Subramanian P, Hasan NA, Colwell RR, Bork P, AzeredoEspin AML, Bryant DA, Schuster SC (2017) The microbiomes of blowflies and houseflies as bacterial transmission reservoirs. Sci Rep 7:16324

Jurkevitch E, Minz D, Ramati B, Barel G (2000) Prey range characterization, ribotyping, and diversity of soil and rhizosphere Bdellovibrio spp. Isolated on Phytopathogenic Bacteria. Appl Environ Microbiol 66:2365-2371

Kang M, Kim SJ, Yoon SR, Lee HW, Lee JY, Ha JH (2019) Determination of transfer patterns of Pectobacterium carotovorum subsp. carotovorum planktonic cells and biofilm during mechanical cutting of Kimchi cabbage. J Food Sci 84:2603-2609

Kastelein P, Forch M, Krijger M, van der Zouwen P, van den Berg W, van der Wolf J (2020) Systemic colonization of potato plants resulting from potato haulm inoculation with Dickeya solani and Pectobacterium parmentieri. Can J Plant Pathol (in press)

Khayi S, Blin P, Pédron J, Chong T-M, Chan K-G, Moumni M, Hélias V, Van Gijsegem F, Faure D (2015) Population genomics reveals additive and replacing horizontal gene transfers in the emerging pathogen Dickeya solani. BMC Genom 16:788

Kikumoto T, Sakamoto M (1969) Ecological studies on the soft rot bacteria of vegetables. VII. The preferential stimulation of the soft rot bacteria in the rhizosphere of crop plants and weeds. Ann Phytopathol Soc Jpn 35:36-40

Kloepper JW, Harrison MD, Brewer JW (1979) The association of Erwinia carotovora var. atroseptica and Erwinia carotovora var carotovora with insects in colorado. Am Potato J 56:351-361

Kloepper JW, Brewer J, Harrison MD (1981) Insect transmission of Erwinia carotovora var. carotovora and Erwinia carotovora var. atroseptica to potato plants in the field. Am Potato J 58:165-175

Krzyzanowska DM, Potrykus M, Golanowska M, Polonis K, Gwizdek-Wisniewska A, Lojkowska E et al (2012) Rhizosphere bacteria as potential biocontrol agents against soft rot caused by various Pectobacterium and Dickeya spp. strains. J Plant Pathol 94:367-378

Kubheka G, Coutinho T, Moleleki N, Moleleki L (2013) Colonisation patterns of an mCherrytagged Pectobacterium carotovorum subsp. brasiliense strain in potato plants. Phytopathology 103:1268-1279

Kumar A, Hunjan MS, Kaur H, Dhillon HK, Singh PP (2017) Biochemical responses associated with resistance to bacterial stalk rot caused by Dickeya zeae in maize. J Phytopathol 165:822-832

Kwan G, Charkowski AO, Barak JD (2013) Salmonella enterica suppresses Pectobacterium carotovorum subsp. carotovorum population and soft rot progression by acidifying the microaerophilic environment. mBio 4:e00557-12

Lapwood DH, Harris RI (1982) The spread of Erwinia carotovora subsp. atroseptica and subsp. carotovora from stem lesions and degenerating seed tubers to progeny tubers in soil. Potato Res 25:41-50 
Laurila J, Ahola V, Lehtinen A et al (2008) Characterization of Dickeya strains isolated from potato and river water samples in Finland. Eur J Plant Pathol 122:213-225

Laurila J, Hannukkala A, Nykyri J et al (2010) Symptoms and yield reduction caused by Dickeya spp. strains isolated from potato and river water in Finland. Eur J Plant Pathol 126:249-262

Leach JG (1926) The relation of the seed-corn maggot (Phorbia fusciceps Zett.) to the spread and development of potato blackleg in Minnesota. Phytopathology 16:149-176

Leigh J, Coplin D (1992) Extrapolysaccharides in plant-bacterial interactions. Annu Rev Microbiol 46:307-346

Li B, Qui W, Fang Y, Xie GL (2009) Bacterial stem rot of Oncidium orchid caused by a Dickeya sp. (ex Pectobacterium chrysanthemi) in mainland China. Plant Dis 93:552-552

Li WQ, Jia YL, Liu FQ, Wang FQ, Fan FJ, Wang J, Zhu JY, Xu Y, Zhong WG, Yang J (2018a) Genome-wide identification and characterization of long non-coding RNAs responsive to Dickeya zeae in rice. RSC Adv 8:34408

Li Z, Wang T, Luo X, Li X, Xia C, Zhao Y et al (2018b) Biocontrol potential of Myxococcus sp. strain BS against bacterial soft rot of calla lily caused by Pectobacterium carotovorum. Biol Control 126:36-44

Lim JA, Jee S, Lee DH, Roh E, Jung K, Oh C et al (2013) Biocontrol of Pectobacterium carotovorum subsp. carotovorum using bacteriophage PP1. J Microbiol Biotechnol 23:1147-1153

Lin YH, Lee PJ, Sjie WT, Chern LL, Chao YC (2015) Pectobacterium chrysanthemi as the dominant causal agent of bacterial soft rot in Oncidium 'Grower Ramsey.' Eur J Plant Pathol 142:331-343

Lipsky A, Cohen A, Ion A, Yedidia I (2014) Genetic transformation of Ornithogalum via particle bombardment and generation of Pectobacterium carotovorum-resistant plants. Plant Sci 228:150 158

Littlejohn GM (2006) Star of bethlehem Ornithogalum. In: Anderson NO (ed) Flower breeding and genetics. Springer Netherlands, Amsterdam , pp 739-752

Liu H, Coulthurst SJ, Pritchard L, Hedley PE, Ravensdale M, Humphris S, Burr T, Gunnhild T, Brurberg M-B, Birch PRJ, Salmond GCP, Toth IK (2008) Quorum sensing coordinates brute force and stealth modes of infection in the plant pathogen Pectobacterium atrosepticum. PLoS Pathog 4:e1000093

Liu H, Zhou M, Yang L, Luo W, Che S, Su J, Zhao B, Lu Y, Hu B, Fan J (2019) First report of Pectobacterium carotovorum subsp. brasiliense causing soft rot on Raphanus sativus in China. Plant Dis 103:1409-1409

Liu QG, Zhang Q, Wei CD (2013) Advances in research of rice bacterial foot rot. Sci Agric Sin 46:2923-2931

Lopez CA, Stall RE, Bartz JA (1986) Bacterial stork and top rot of maize in Florida caused by Erwinia chrysanthemi pv zeae. Plant Dis 70:259-259

Luzzatto T, Yishay M, Lipsky A, Ion A, Belausov E, Yedidia I (2007) Efficient, long-lasting resistance against the soft rot bacterium Pectobacterium carotovorum in calla lily provided by the plant activator methyl jasmonate. Plant Pathol 56:692-701

Ma B, Hibbing ME, Kim HS, Reedy RM, Yedidia I, Breuer J, Glasner JD, Perna N, Kelman A, Charkowski AO (2007) Host range and molecular phylogenies of the soft rot enterobacterial genera Pectobacterium and Dickeya. Phytopathology 97:1150-1163

Maddox D, Harrison M (1988) Presence and population dynamics of Erwinia carotovora in irrigation water in south central Colorado. J Appl Bacteriol 64:169-182

Mahmoudi E, Soleimani MJ, Taghavi M (2007) Defection of bacterial soft rot of crown imperial caused by Pectobacterium carotovorum subsp carotovorum using specific PCR primers. Phytopathologia Mediterranea 46:168-176

Antunez-Lamas M, Cabrera-Ordonez E, Lopez-Solanilla E, Raposo R, Trelles-Salazar O, Rodriguez-Moreno A, Rodriguez-Palenzuela P (2009) Role of motility and chemotaxis in the pathogenesis of Dickeya dadantii 3937 (ex Erwinia chrysanthemi 3937). Microbiology 155:434-442

Martinez-Cisneros BA, Juarez-Lopez G, Valencia-Torres N, Duran-Peralta E, Mezzalama M (2014) First report of bacterial stalk rot of maize caused by Dickeya zeae in Mexico. Plant Dis 98:1267 
Martinson VG, Carpinteyro-Ponce J, Moran NA, Markow TA (2017) A distinctive and hostrestricted gut microbiota in populations of a cactophilic Drosophila species. Appl Environ Microbiol 83:e01551-e11517

McCarter-Zorner NJ, Harrison MD, Franc GD, Quinn CE, Sells IA, Graham DC (1985) Soft rot Erwinia bacteria in the rhizosphere of weeds and crop plants in Colorado USA and Scotland UK. J Appl Bacteriol 59:357-368

McCarter-Zorner NJ, Franc GD, Harrison MD, Michaud JE, Quinn CE, Sells IA, Graham DC (1984) Soft rot Erwinia bacteria in surface and underground waters in southern Scotland and in Colorado, United States. J Appl Bacteriol 57:95-105

McMillan RT, Palmateer A, Vendrame W (2007) Effect of roguing on Erwinia soft rot in commercial production with two Phalaenopsis plants per pot. Proc Florida State Horticult Soc 120:353-355

Mejia-Sanchez D, Aranda-Ocampo S, Nava-Diaz C, Teliz-Ortiz D, Livera-Munoz M, De La TorreAlmaraz R, Ramirez-Alarcon S (2019) Pectobacterium carotovorum subsp. brasiliense causes soft rot and death of Neobuxbaumia tetetzo in Zapotitlan Salinas Valley, Puebla, Mexico. Plant Dis 103:398-403

Meneley JC, Stanghellini ME (1976) Isolation of soft rot Erwinia spp. from agricultural soils using an enrichment technique. Phytopathology 66:367-370

Miles LA, Lopera CA, González S, de García MCC, Franco AE, Restrepo S (2012) Exploring the biocontrol potential of fungal endophytes from an Andean Colombian Paramo ecosystem. Biocontrol 57:697-710

Molina JJ, Harrison MD, Brewer JW (1974) Transmission of Erwinia carotovora var. atroseptica by Drosophila melanogaster Meig. I. Acquisition and transmission of the bacterium. Am J Potato Res 51:245-250

Morris CE, Monteil CL, Berge O (2013) The Life History of Pseudomonas syringae: Linking Agriculture to Earth System Processes. Annu Rev Phytopathol 51:85-104

Nabhan S, De Boer SH, Maiss E, Wydra K (2013) Pectobacterium aroidearum sp. nov., a soft rot pathogen with preference for monocotyledonous plants. Int J Syst Evol Microbiol 63:2520-2525

Nabhan S, Wydra K, Linde M, Debener T (2012) The use of two complementary DNA assays, AFLP and MLSA, for epidemic and phylogenetic studies of pectolytic enterobacterial strains with focus on the heterogeneous species Pectobacterium carotovorum. Plant Pathol 61:498-508

Neevesbrun C (1985) Infection of roots of Diffenbachia-maculata by the foliar blight and soft rot pathogen Erwinia chrysanthemi. Plant Pathol 34:139-145

Noel JT, Joy J, Smith JN, Fatica M, Schneider KR, Ahmer BM, Teplitski M (2010) Salmonella SdiA recognizes $\mathrm{N}$-acyl homoserine lactone signals from Pectobacterium carotovorum in vitro, but not in a bacterial soft rot. Mol Plant Microbe Interact 23:273-282

Nor AAM, Zainol R, Abdullah R, Jaffar NS, Rasid MZA, Laboh R, Shafawi NA, Aziz NBA (2019) Dissemination pattern of bacterial heart rot (BHR) disease and screening of the disease resistance among commercial pineapple varieties in Malaysia. Malaysian J Microbiol 15:346-350

Norman D, Yuen J, Resendiz R, Boswell J (2003) Characterization of Erwinia populations from nursery retention ponds and lakes infecting ornamental plants in Florida. Plant Dis 87:193-196

Nykyri J, Fang X, Dorati F, Bakr R, Pasanen M, Niemi O, Palva ET, Jackson RW, Pirhonen M (2014) Evidence that nematodes may vector he soft rot-causing enterobacterial phytopathogens. Plant Pathol 63:747-757

Ogoshi C, Monteiro FP, Becker WF, Kvitschal MV, Cardoza YF, Zanin JG, Duarte V (2019) First report of Dickeya dadantii causing a new disease of apple trees in Brazil. New Dis Rep 39:8-8

Olsson K (1985) Detection of Erwinia spp. in some Swedish streams. Report of the international conference on potato blackleg disease, pp 45-46

Oulghazi S, Pédron J, Cigna J, Lau YY, Moumni M, Van Gijsegem F, Chan KG, Faure D (2019) Dickeya undicola sp. nov., a novel species for pectolytic isolates from surface waters in Europe and Asia. Int J Syst Evol Microbiol 69:2440-2444

Oulghazi S, Cigna J, Lau YY, Moumni M, Chan KG, Faure D (2019) Transfer of the waterfall source isolate Pectobacterium carotovorum M022 to Pectobacterium fontis sp. Nov., a deep-branching species within the genus Pectobacterium. Int J Syst Evol Microbiol 69:470-475 
Palacio-Bielsa A, Mosquera MER, MaC Á, Rodríguez IMB, López-Solanilla E, RodríguezPalenzuela P (2010) Phenotypic diversity, host range and molecular phylogeny of Dickeya isolates from Spain. Eur J Plant Pathol 127:311-324

Park DS, Oh HW, Jeong WJ, Kim H, Park HY, Bae KS (2007) A culture-based study of the bacterial communities within the guts of nine longicorn beetle species and their exo-enzyme producing properties for xylan and pectin. J Microbiol 45:394-401

Parkinson N, Devos P, Pirhonen M, Elphinstone J (2014a) Dickeya aquatica sp. nov., isolated from waterways. Int J Syst Evol Microbiol 64:2264-2266

Parkinson N, Pritchard L, Bryant R, Toth IK, Elphinstone JE (2014b) Epidemiology of Dickeya dianthicola and Dickeya solani in ornamental hosts and potato studied using variable number tandem repeat analysis. Eur J Plant Pathol 141:63-70

Parkinson N, Stead D, Bew J, Heeney J, Tsror L, Elphinstone J (2009) Dickeya species relatedness and clade structure determined by comparison of recA sequences. Int J Syst Evol Microbiol 59:2388-2393

Pasanen M, Waleron M, Schott T, Cleenwerck I, Misztak A, Waleron K, Pritchard L, Bakr R, Degefu Y, van der Wolf J, Vandamme P, Pirhonen M (2020) Pectobacterium parvum sp. nov., having a Salmonella SPI-1-like Type III secretion system and low virulence. Int J Syst Evol Microbiol. doi https://doi.org/10.1099/ijsem.0.004057

Pédron J, Van Gijsegem F (2019) Diversity in the bacterial genus Dickeya grouping plant pathogens and waterways isolates. OBM Genetics 3:22

Pédron J, Bertrand C, Taghouti G, Portier P, Barny MA (2019) Pectobacterium aquaticum sp. nov, isolated from waterways. Int J Syst Evol Biol 69:745-751

Peltzer S, Sivasithamparam K (1988) Sero-groups of Erwinia carotovora associated with water, soil, tuber, and stems of potato plants in Western Australia. New Zealand J Exp Agric 16:265-270

Pérombelon M, Hyman L (1987) Frequency of Erwinia carotovora in the Alyth Burn in eastern Scotland and the sources of the bacterium. J Appl Bacteriol 63:281-291

Pérombelon M, Hyman L (1989) Survival of soft rot coliforms, Erwinia carotovora subsp. carotovora and E. carotovora subsp. atroseptica in soil in Scotland. J Appl Bacteriol 66:95-106

Pérombelon MC, Kelman A (1980) Ecology of the soft rot erwinias. Annu Rev Phytopathol 18:361387

Pérombelon MCM (1992) Potato blackleg: epidemiology, host-pathogen interaction and control. Netherlands J Plant Pathol 98(Suppl. 2):135-146

Pérombelon MCM, Kelman A (1987) Blackleg and other potato diseases caused by soft rot erwinias; proposal for revision of terminology. Plant Dis 71:283-285

Pérombelon MCM, Lumb VM, Zutra D, Hyman LJ, Burnett EM (1989) Factors affecting potato blackleg development. In: Tjamos EC, Beckman CH (eds) Proceedings of the NATO advanced research workshop on 'the interaction of genetic and environmental factors in the development of vascular wilt diseases of plants' 1988. Springer-Verlag, Cape Sounion, Greece. Berlin, pp 421-431

Pérombelon MCM, Salmond GPC (1995) Bacterial soft rot. In: Singh RP, Kohmoto K (eds) Singh US. Pathogenesis and host specificity in plant diseases, Pergamon Press, pp 1-20

Pérombelon MCM (2002) Potato diseases caused by soft rot erwinias: an overview of pathogenesis. Plant Pathol 51:1-12

Phillips JA, Kelman A (1982) Direct fluorescent antibody stain procedure applied to insect transmission of Erwinia carotovora. Phytopathology 72:898-901

Portier P, Pédron J, Taghouti G, Fischer-Le Saux M, Caullireau E, Bertrand C, Laurent A, Chawki K, Oulgazi S, Moumni M, Andrivon D, Dutrieux C, Faure D, Helias V, Barny MA (2019) Elevation of Pectobacterium carotovorum subsp. odoriferum to species level as Pectobacterium odoriferum sp. nov., proposal of Pectobacterium brasiliense sp. nov. and Pectobacterium actinidiae sp. nov., emended description of Pectobacterium carotovorum and description of Pectobacterium versatile sp. nov., isolated from streams and symptoms on diverse plants. Int J Syst Evol Microbiol 69:32143223 
Potrykus M, Golanowska M, Sledz W, Zoledowska S, Motyka A et al (2016) Biodiversity of Dickeya spp. isolated from potato plants and water sources in temperate climate. Plant Dis 100:408-417

Powelson ML, Apple JD (1984) Soil and seed tubers as sources of inoculum of Erwinia carotovora pv. carotovora for stem soft rot potatoes. Phytopathology 74:429-432

Pritchard L, Humphris S, Saddler GS, Elphinstone JG, Pirhonen M. Toth IK (2013) Draft genome sequences of 17 isolates of the plant pathogenic bacterium Dickeya. Genome Announcements 1:10.1128/genomeA.00978-13

Pu XM, Zhou JN, Lin BR, Shen HF (2012) First report of bacterial foot rot of rice caused by a Dickeya zeae in China. Plant Dis 96:1818

Rangarajan M, Chakravarti BP (1970) Studies on the survival of corn stalk rot bacteria. Plant Soil 33:140-144

Rojas CM, Ham JH, Deng WL, Doyle JJ, Collmer A (2002) HecA, a member of a class of adhesins produced by diverse pathogenic bacteria, contributes to the attachment, aggregation, epidermal cell killing and virulence phenotype of Erwinia chrysanthemi EC16 on Nicotiana clevelandii seedlings. Proc Natl Acad Sci USA 99:13142-13147

Rossmann S, Dees MW, Perminow J, Meadow R, Brurberg MB (2018) Soft rot Enterobacteriaceae are carried by a large range of insect species in potato fields. Appl Environ Microbiol 84:UNSPe00281

Sadeghi-Seraii J, Khodakaramian G, Rouhrazi K (2018) First report of garlic soft rot caused by Pectobacterium carotovorum subsp carotovorum in Iran. J Plant Pathol 100:125-125

Samson R, Legendre JB, Christen R, Fischer-Le Saux M, Achouak W, Gardan L (2005) Transfer of Pectobacterium chrysanthemi (Burkholder et al. 1953) Brenner et al. 1973 and Brenneria paradisiaca to the genus Dickeya gen. nov as Dickeya chrysanthemi comb. nov and Dickeya paradisiaca comb. nov and delineation of four novel species, Dickeya dadantii sp nov., Dickeya dianthicola sp nov., Dickeya dieffenbachiae sp nov and Dickeya zeae sp nov. Int J Syst Evol Microbiol 55:1415-1427 (32)

Sarfraz S, Riaz K, Oulghazi S, Cigna J, Sahi ST, Khan SH, Faure D (2018) Pectobacterium punjabense sp nov., isolated from blackleg symptoms of potato plants in Pakistan. Int J Syst Evol Microbiol 68:3551-3556

EFSA (2013) Scientific Opinion on the risk of Dickeya dianthicola for the EU territory with identification and evaluation of risk reduction options. EFSA J 11:3072

Seo ST, Furuya N, Lim CK, Takanami Y, Tsuchiya K (2002) Phenotypic and genetic diversity of Erwinia carotovora ssp. carotovora strains from Asia. J Phytopathol 150:120-127

Smid EJ, Jansen AHJ, Tuijn CJ (1993) Anaerobic nitrate respiration by Erwinia carotovora subsp. atroseptica during potato tuber invasion. Appl Environ Microbiol 59:3648-3653

Smith C, Bartz JA (1990) Variation in the pathogenicity and aggressiveness of strains of Erwinia carotovora subsp. carotovora Isolated from different hosts. Plant Dis 74:505-509

Snehalatharani A, Khan AN (2010) Biochemical and physiological characterization of Erwinia species causing tip-over disease of banana. Arch Phytopathol Plant Protect 43:1072-1080

Snijder RC, Van Tuyl JM (2002) Evaluation of tests to determine resistance of Zantedeschia spp. Araceae to soft rot caused by Erwinia carotovora subspecies carotovora. Eur J Plant Pathol 108:565-571

Sudarsono S, Elina J, Giyanto G, Sukma D (2018) Pathogen causing Phalaenopsis soft rot disease16S rDNA and virulence characterization. Plant Prot Sci 54:1-8

Sueno W, Marrero G, De Silva A, Sether D, Alvarez A (2014) Diversity of Dickeya strains collected from pineapple plants and irrigation water in Hawaii. Plant Dis 98:817-824

Suharjo R, Sawada H, Takikawa Y (2014) Phylogenetic study of Japanese Dickeya spp. and development of new rapid identification methods using PCR-RFLP. J Gen Plant Pathol 80:237-254

Thind BS, Singh N (1975) Maize borer (Chilo partellus) as carrier of Erwinia carotovora var. zeae, the causal agent of bacterial stalk rot of maize. Curr Sci 45:117-118 
Tian Y, Zhao Y, Yuan X, Yi J, Fan J, Xu Z, Hu B, De Boer SH, Li X (2016) Dickeya fangzhongdai sp. nov., a plant pathogenic bacterium isolated from pear trees (Pyrus pyrifolia). Int J Syst Evol Microbiol 66:2831-2835

Toth IK, Humphris S, Campbell E, Pritchard L (2015) Why genomics research on Pectobacterium and Dickeya makes a difference. Am J Potato Res 92:218-222

Toth IK, Pritchard L, Birch PRJ (2006) Comparative genomics reveals what makes an enterobacterial plant pathogen. Annu Rev Phytopathol 44:305-336

Toth IK, van der Wolf JM, Saddler G, Lojkowska E, Hélias V, Pirhonen M, Tsror (Lahkim) L, Elphinstone JG, (2011) Review: Dickeya species: An emerging problem for potato production in Europe. Plant Pathol 60:385-399

Tsai WA, Lin PR, Huang CJ (2019) First report of Dickeya fangzhongdai causing soft rot disease of Welsh onion in Taiwan. J Plant Pathol 101:797-798

Tsror (Lahkim) L, Ben-Daniel B, Chalupowicz L, van der Wolf J, Lebiush S, Erlich O, Dror O, Barel V, Nijhuis E, Manulis-Sasson S, (2013) Characterization of Dickeya strains isolated from potato grown under hot-climate conditions. Plant Pathol 62:1097-1105

Tsror L, Erlich O, Lebiush S et al (2009) Assessment of recent outbreaks of Dickeya sp. (syn. Erwinia chrysanthemi) slow wilt in potato crops in Israel. Eur J Plant Pathol 123:311-320

Tsror L, Erlich O, Lebiush S, Van Der Wolf J, Czajkowski R, Mozes G, Sikharulidze Z, Daniel BB (2011) First report of potato blackleg caused by a biovar 3 Dickeya sp. in Georgia. New Dis Rep 23:1

Tsror L, Lebiush S, Erlich O, Galilov I, Chalupowicz L, Reuven M, Dror O, Manulis-Sasson S (2019) First report of latent infection of Malva nicaeensis caused by Pectobacterium carotovorum subsp. brasiliense in Israel. New Dis Rep 39:4

van der Wolf J, Czajkowski R, Velvis H (2009) Effectieve kolonisatie van aardappelplanten door Dickeya soorten (Erwinia chrysanthemi). Gewasbescherming Jaargang 4:169-171

Van der Wolf JM, Nijhuis EH, Kowalewska MJ, Saddler GS, Parkinson N, Elphinstone JG, Pritchard L, Toth IK, Lojkowska E, Potrykus M, Waleron M, de Vos P, Cleenwerck I, Pirhonen M, Garlant L, Helias V, Pothier JF, Pfluger V, Duffy B, Tsror L, Manulis S (2014) Dickeya solani sp. Nov., a pectolytis plant-pathogenic bacterium isolated from potato (Solanum tuberosum). Int J Syst Evol Microbiol 64:768-774

van Doorn J, Vreeburg PJM, van Leeuwen PJ, Dees RHL (2011) The presence and survival of soft rot (Erwinia) in flower bulb production systems. Acta Horticulurae 886:365-379

Velvis H, van der Wolf J (2008) Project Bacterievrije Pootgoedteelt - een Uitdaging! Eindrapport van het Ond erzoek. [Bacterium-free Seed Production Project - a Challenge. Final Report of the Investigation]. A project financially supported by the EU, the province of Flevoland, LIB, Rabobank and Interpolis Agro. https://www.kennisakker.nl

Waleron M, Misztak A, Waleron M, Franczuk M, Wielgomas B, Waleron K (2018) Transfer of Pectobacterium carotovorum subsp carotovorum strains isolated from potatoes grown at high altitudes to Pectobacterium peruviense sp nov. Syst Appl Microbiol 41:85-93

Waleron M, Misztak A, Waleron M, Franczuk M, Jonca J, Wielgomas B, Mikicinski A, Popovic T, Waleron K (2019b). Pectobacterium zantedeschiae sp. nov. a new species of a soft rot pathogen isolated from Calla lily (Zantedeschia spp.) Syst Appl Microbiol 42:275-283

Waleron M, Misztak A, Waleron M, Jonca J, Furmaniak M, Waleron K (2019) Pectobacterium polonicum sp. nov. isolated from vegetable fields. Int J Syst Evol Microbiol 69:1751-1759

Wang H, Yang Zhongling DuS, Ma L, Liao Y, Wang Y, Toth IK, Fan J (2018) Characterisation of Pectobacterium carotovorum proteins differentially expressed during infection of Zantedeschia elliotiana in vivo and in vitro which are essential for virulence. Mol Plant Pathol 19:35-48

Wang H, Jin L, Zhang H (2011) Comparison of the diversity of the bacterial communities in the intestinal tract of adult Bactrocera dorsalis from three different populations. J Appl Microbiol 110:1390-1401

Wang X, He S-W, Guo H-B, Han J-G, Thin KK, Gao J-S, Yao Wang Y and Zhang X-X (2020) Dickeya oryzae sp. nov., isolated from the roots of rice. Int J Syst Evol Microbiol ijsem004265 
Wei X-Y, Chiu Y-H, Deng W-L, Chu C-C (2018) First report of Dickeya dadantii causing stem rot of poinsettia in Taiwan. Plant Dis 103:143-144

Wells JM, Butterfield JE (1997) Salmonella contamination associated with bacterial soft rot of fresh fruits and vegetables in the marketplace. Plant Dis 81:867-872

Welte CU, de Graaf RM, van den Bosch TJM, Op den Camp HJM, van Dam NM, Jetten MSM (2015) Plasmids from the gut microbiome of cabbage root fly larvae encode SaxA that catalyses the conversion of the plant toxin phenylethyl isothiocyanate. Environ Microbiol 18:1379-1390

Welte CU, Rosengarten JF, de Graaf RM, Jetten MSM (2016) SaxA-mediated isothiocyanate metabolism in phytopathogenic pectobacteria. Appl Environ Microbiol 82:2372-2379

Wright PJ, Clark GE, McLachlan ARG (2011) Effects of wounding, inoculation with Erwinia carotovora subsp. carotovora, water logging and temperature on incidence of bacterial soft rot in calla lilly. In: X International symposium on flower bulbs and herbaceous perennials, vol 886, pp 399-405

Wright PJ (1998) A soft rot of calla (Zantedeschia spp.) caused by Erwinia carotovora subspecies carotovora. New Zealand J Crop Horticult Sci 26:331-334

Xie H, Li XY, Ma YL, Tian Y (2018) First report of Pectobacterium aroidearum causing soft rot of chinese cabbage in China. Plant Dis 102:674-674

Yamazaki A, Li J, Hutchins WC, Wang L, Ma J, Ibekwe AM, Yang CH (2011) Commensal effect of pectate lyases secreted from Dickeya dadantii on proliferation of Escherichia coli O157:H7 EDL933 on lettuce leaves. Appl Environ Microbiol 77:156-162

Yan MF, Liu B, Zou MF, Zhou Y, Jiang JX (2019) First report of summer canker caused by Pectobacterium carotovorum subsp. actinidiae on kiwifruit in Jiangxi, eastern China. J Plant Pathol 101:789-789

Yang QY, Jiang SB, Zhang JX, Shen HF, Sun DY, Pu XM, Lin BR (2018) First report of Dickeya zeae causing bacterial soft rot on Canna edulis in China. Plant Dis 103:146-146

Yedidia I, Ophir R, Yishay M, Ion A, Luzzatto T, Golan A, Burdman S (2011) A story of an old battle: Pectobacterium carotovorum and ornamental monocots. Acta Hort 886:417-425

Ying FX, Hu XF, Chen JS (2007) First report of soft rot caused by Pectobacterium carotovorum on Pinellia ternata in China. Plant Dis 91:1359

Yishay M, Burdman S, Valverde A, Luzzatto T, Ophir R, Yedidia I (2008) Differential pathogenicity and genetic diversity among Pectobacterium carotovorum ssp. carotovorum isolates from monocot and dicot hosts support early genomic divergence within this taxon. Environ Microbiol 10:2749-2759

Zaczek-Moczydlowska MA, Fleming CC, Young GK, Campbell K, O'Hanlon R (2019) Pectobacterium and Dickeya species detected in vegetables in Northern Ireland. Eur J Plant Pathol 154:635-647

Zhang JX, Hu J, Shen HF, Zhang YC, Sun DY, Pu XM, Yang QY, Fan QR, Lin BR (2018) Genomic analysis of the Phalaenopsis pathogen Dickeya sp. PA1, representing the emerging species Dickeya fangzhongdai. BMC Genom 19:782

Zhang JX, Shen HF, Pu XM (2014) Identification of Dickeya zeae as a causal agent of bacterial soft rot in banana in China. Plant Dis 98:436-442

Zhou JN, Lin BR, Shen HF, Pu XM, Chen ZN, Feng JJ (2012) First report of a soft rot of Phalaenopsis aphrodite caused by Dickeya dieffenbachiae in China. Plant Dis 96:760-760

Zlatkovic N, Prokic A, Gasic K, Kuzmanovic M, Ivanovic M, Obradovic A (2019) First report of Pectobacterium carotovorum subsp. brasiliense causing soft rot on squash and watermelon in Serbia. Plant Dis 103:2667-2667

Zoledowska S, Motyka A, Zukowska D, Sledz W, Lojkowska E (2018) Population structure and biodiversity of Pectobacterium parmentieri isolated from potato fields in temperate climate. Plant Dis 102:154-164 